Portland State University

PDXScholar

2010

\title{
"Real Americanism" : resistance to the Oregon Compulsory School Bill, 1920-1925
}

Catherine Marie Saks

Portland State University

Follow this and additional works at: https://pdxscholar.library.pdx.edu/open_access_etds

Part of the History Commons

Let us know how access to this document benefits you.

\section{Recommended Citation}

Saks, Catherine Marie, "'Real Americanism" : resistance to the Oregon Compulsory School Bill, 1920-1925" (2010). Dissertations and Theses. Paper 4164.

https://doi.org/10.15760/etd.6036

This Thesis is brought to you for free and open access. It has been accepted for inclusion in Dissertations and Theses by an authorized administrator of PDXScholar. Please contact us if we can make this document more accessible: pdxscholar@pdx.edu. 


\section{THESIS APPROVAL}

The abstract and thesis of Catherine Marie Saks for the Master of Arts in History were presented February 9, 2010, and accepted by the thesis committee and the department. COMMTTTEE APPROVALS:

Tim Garrison, Chair

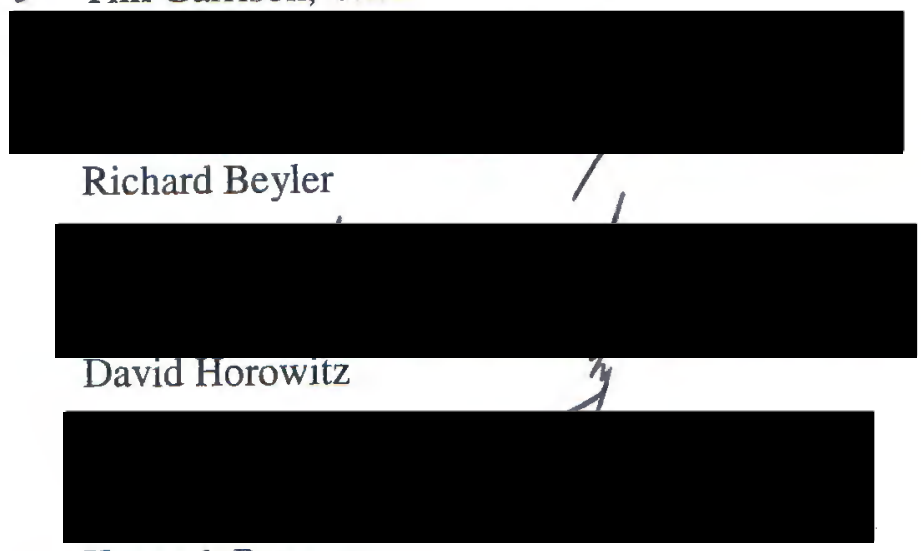

Kenneth Peterson

DEPARTMENT APPROVAL:

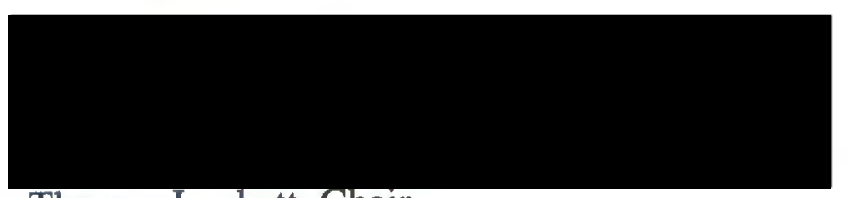

Thomas Luckett, Chair

Department of History 


\section{ABSTRACT}

An abstract of the thesis of Catherine Marie Saks for the Master of Arts in History presented February 9, 2010.

Title: "Real Americanism": Resistance to the Oregon Compulsory School Bill, 1920-1925.

The early 1920s are generally described as a period of transition for American society. Many forces of change collided to create an unsettled atmosphere that appeared to threaten traditional American ideas and values. After World War I, the United States fostered a climate of anti-Catholicism and nativism out of fear that foreign ideas spelled the demise of traditional American values. These ideas were certainly not new to American culture as anti-Catholic sentiments figured prominently throughout the founding of the nation. During the early 1920 s, however, a resurrected $\mathrm{Ku}$ Klux Klan promoted itself as the protector of American institutions. It won recruits with an identity as a secret society for white, Anglo-Saxon, Protestant citizens. The organization also exploited the political issues of the day to ingratiate itself within communities across the nation.

Oregon proved to be especially fertile ground for Klan recruiters. The state was a relatively conservative, homogenous society. Therefore, Klan leaders believed that Oregon was the perfect place to launch a national political platform that included 
support for public education. Klan influence played a significant role in persuading Oregonians to pass the Compulsory School Bill in the November 1922 state election. The new law would require that all children ages eight to sixteen attend public schools. This had disastrous implications for private schools, particularly Catholic schools, which had been a favorite target of Klan propaganda. These schools faced certain closure when the bill was to go into effect in 1926. Although the Klan denied that the measure was fueled by anti-Catholicism, the Klan's anti-Catholic views were widely known and even accepted.

Despite the power of the Klan's influence, opposition to the school measure existed and proved instrumental in testing the constitutionality of the school bill. The work of the staff at the Portland-based newspaper, the Catholic Sentinel, represents a significant effort to educate Catholics about the court fight. These tireless efforts culminated in the Supreme Court's decision in Pierce v. Society of Sisters to uphold the ruling of the lower courts that the school bill was unconstitutional. 
"REAL AMERICANISM":

RESISTANCE TO THE OREGON COMPULSORY SCHOOL BILL, $1920-1925$

by

CATHERINE MARIE SAKS

A thesis submitted in partial fulfillment of the requirements for the degree of

\author{
MASTER OF ARTS \\ in \\ HISTORY
}

Portland State University

2010 
Contents

Introduction

Oregon and the Compulsory School Bill.

Chapter One

A Brief History of Anti-Catholicism in the United States............ 7

Chapter Two

A Brief History of Anti-Catholicism in Oregon.................... 33

Chapter Three

The Compulsory School Bill..................................... 59

Chapter Four

The Catholic Sentinel and the Challenge in the Courts............... 87

Chapter Five

The U.S. Supreme Court Decision............................ 102

Conclusion

Post Pierce Prejudice

Sources Consulted 
Introduction

Oregon and the Compulsory School Bill

In the November 1922 state elections, Oregonians approved Measure 315, the Compulsory School Bill. This bill required all school children ages eight to sixteen to attend public schools, removing the exemption that allowed children to attend parochial and private schools.' The bill threatened to decimate all private educational institutions throughout the state. Although the Scottish Rite Masons initially sponsored the bill, the Ku Klux Klan picked up the torch of public education and led a powerful, albeit brief, movement against Catholic education during the $1920 \mathrm{~s}$. The passage of the school bill in Oregon created important considerations because it was not simply the success story of a short-lived revival of the Klan. Rather, the school bill reflected Oregon's culture and history, where anti-Catholicism had been common for decades.

Oregon's anti-Catholicism was part of a long-lasting national phenomenon. American independence from England, though often touted not only as a break from England but a split from traditional, Old World European culture, did not represent the end of anti-Catholic prejudice. As the United States entered the 1800 s, immigration proved to be the main factor that kept anti-Catholicism alive throughout the nineteenth century. As immigration rates to the U.S. increased during the 1830 s and 1840 s with the arrival of the Irish, and again during the $1880 \mathrm{~s}$ and $1890 \mathrm{~s}$, with the arrival of many

\footnotetext{
1 A.B. Cain, The Oregon School Fight: A True and Complete History (Portland, Oregon: A.B. Cain,
} Publisher, 1924), 5. 
Italian and Polish immigrants, anti-Catholicism continued to be a common prejudice among many Americans. Anti-Catholicism, when combined with a growing nativist movement, proved to be a powerful combination. Throughout the late nineteenth century, nativists sought to protect the advantages and privileges of native-born citizens against the wave of foreign-born newcomers. Nativist organizations feared competition from immigrants for jobs, and as the labor force continued to unionize into the late 1800 s and early 1900 s, many nativist groups feared the promotion of anarchism and socialism commonly associated with early union movements. Unions protested low wages and poor working conditions, drawing membership largely from immigrants who suffered from these circumstances. Because many labor organizers, at the very least, empathized with basic socialist doctrine, unions gained reputations for fostering ideas contradictory to American democratic beliefs.

Among the foreign elements deemed dangerous was the Roman Catholic Church. Anti-Catholic demagogues argued that Catholic immigrants followed directives from the papacy, a foreign entity that demanded loyalty to itself over any loyalty to one's own nation. Catholic schools, in particular, were supposedly institutions to be feared because they indoctrinated Catholics from a very young age to cultivate that allegiance to a distant foreign entity. According to anti-Catholic leaders, these schools isolated children away from mainstream America in an effort to foster loyalty to an outside leader that historically exercised absolute authority over all Church matters and one that did not have the interests of the United States at heart. Therefore, in the early twentieth century, the development of the public school system 
commanded great attention as the vehicle by which immigrants could be deterred from Catholic loyalties and taught proper American ideas and values. When the United States entered into World War I, it proved particularly important to nativists that Americans unite under a common set of democratic values, rather than maintain allegiances to foreign powers or institutions.

During the post-war era, and into the 1920s, many Americans hoped for a return to normalcy, as Warren Harding promised during the 1920 presidential campaign. According to historian Malcolm Clark, this represented a hope among some Americans for a transition back to a traditional lifestyle where supposedly the Protestant ethic governed the morality of the country, and the economic vitality of the nation centered on the family farm. Under this view, women were to focus their efforts around the home, and laboring men simply worked for their employers without protest. It proved impossible, however, to return to this imagined past because the war accelerated the nation's transition into a modern, industrialized world power at such a rate that many Americans were caught unprepared for the ramifications of this transition. In some areas, the Protestant ethic crumbled in the face of a combination of factors that included the increasing availability of the automobile and the failure of Prohibition. By 1920, women gained political independence with the passage of the Nineteenth Amendment. Laboring men worked not on the family farm, but in the factory. For many traditionalists, it appeared that the nation was compromising its identity. 
Therefore, the early 1920 s proved to be dramatic and unsettling as all of these forces collided. The unsettled nature of this time period is best exemplified with the backlash against organized labor in 1919, defined by the federal government as an effort to reduce radicalism. Attorney General A. Mitchell Palmer authorized the socalled "Red Scare," rounding up and imprisoning hundreds of people for radical and socialist political convictions supposedly contrary to American democratic values. Anti-Catholicism also resurfaced during the early 1920 s as the revived Ku Klux Klan picked up the nativist torch in an effort to recruit new members. The Klan promoted the idea that Catholicism was a foreign belief system intent on the destruction of American democratic ideals. As a result, many Americans gravitated to organizations such as the Klan that promised to protect traditional American values, such as patriotism, popular democracy and moral conservatism, against the negative forces of change. $^{2}$ The Ku Klux Klan fed, and fed off of, the concerns of Americans regarding the future direction of the nation. As Malcolm Clark wrote, "In the winter of 1920-21 the national press took note of a new, as yet no more than curious, phenomenon. Increasing numbers of masked marchers were parading purposefully about, shrouded in bed-sheet robes and appropriately pointed headgear." ${ }^{\prime 3}$ Klan membership increased dramatically during the early 1920 s, and many Americans saw the Klan as a viable political organization that gave legitimacy to their fears and prejudices. In this vein,

\footnotetext{
${ }^{2}$ M. Paul Holsinger, "The Oregon School Controversy, 1922-25," Pacific Historical Review 37 (August 1968): 332.

${ }^{3}$ Malcolm Clark, Jr., "The Bigot Disclosed: Ninety Years of Nativism," Oregon Historical Quarterly 75 , no. 2 (June 1974): 151.
} 
the first Klan recruiters arrived in Oregon in early $1921 .^{4}$ By late 1922 , the Klan achieved considerable political success, not only with the election of certain key officials, including Governor Walter Pierce, but also with the passage of the school bill.

After the bill was passed, a private school, the Hill Military Academy, and the Society of Sisters, filed a lawsuit to challenge the constitutionality of the new law on the grounds that it violated parents' rights to make decisions regarding the education of their children. Attorneys also argued that the school bill violated private property protections inherent in the Fourteenth Amendment. In June of 1925, the United States Supreme Court declared the bill unconstitutional.

Catholic historian Lawrence Saalfeld has lamented the fact that the Klan appeared to effectively silence opposition to the bill. Saalfeld argued that a virtual media silence existed regarding the school bill and that many of the state's newspapers refused to take a stand against the act. ${ }^{5}$ This, however, would appear not to be the case. In fact, despite passage of the bill, a lively political opposition arose to contest the school bill, an opposition that can be seen in the Oregonian, the Portland Telegram, and the Catholic Sentinel, to name a few newspapers. The Sentinel, in particular, provided a long-standing voice against anti-Catholicism, dating back to the 1870s. That opposition did not crumble in the face of defeat when the school bill was

\footnotetext{
${ }^{4}$ David A. Horowitz, ed., Inside The Klavern: The Secret History of a Ku Klux Klan of the 1920s (Carbondale, Illinois: Southern Illinois University Press, 1999), 5.

${ }^{5}$ Lawrence J. Saalfeld, Forces of Prejudice in Oregon: 1920-1925 (Portland, Oregon: University of Portland Press, 1984), 85. See also Robert P. Lockwood, ed., Anti-Catholicism in American Culture (Huntington, Indiana: Our Sunday Visitor, Inc., 2000), 89-104 and Mark S. Massa, S.J., AntiCatholicism in America: The Last Acceptable Prejudice (New York: Crossroad Publishing Co., 2003), 18-39.
} 
passed. Many of its most powerful arguments, as discussed primarily in the Sentinel, proved influential in the final U.S. Supreme Court decision. The Sentinel's historical research and political activism ensured that opposition to Oregon's compulsory school bill was, in the end, powerful and effective.

This thesis will describe the Catholic Sentinel's efforts to oppose the passage of the school bill and the impact of those efforts. The first chapter will briefly survey the history of anti-Catholic activity in U.S. history. The next chapter will discuss antiCatholicism in Oregon's history. The third chapter highlights the arrival of the Ku Klux Klan in Oregon and its political activities as they relate to the campaign of 1922 , when voters passed the school bill. The fourth chapter explains the opposition to the compulsory school bill. The final chapter discusses the decision of Pierce v. Society of Sisters that rendered the school bill unconstitutional, and the Sentinel's coverage of that litigation. 


\section{Chapter 1}

\section{A Brief History of Anti-Catholicism in the United States}

Anti-Catholicism appeared early in America, particularly since early settlers came from an England reeling from the political and social turmoil stemming from the Protestant Reformation. It arrived with the first English settlers who were products of the English Reformation. Initially, the split between Henry VIII and the Roman Catholic Church was more for political, rather than theological, reasons. Henry VIII desired an annulment of his marriage to Catherine of Aragon. The Pope, however, refused to grant the annulment, which ultimately led to Henry's decision to officially break away from the authority of the Pope by establishing the Church of England. Because the English Reformation extended over several generations, the pace of reform within the Church of England ebbed and flowed as well. As a result, many of the settlers arriving in British North America were Puritans, opposed to the Church of England for, among other reasons, not taking reforms far enough to expel all Catholic elements. Those first Puritans promoted prejudices about the Catholic Church that firmly took root in America, namely that the Pope was the power-obsessed leader of a Catholic Church that sought to control all nations and their governments from Rome while promoting Catholic doctrine above all others.

According to Catholic historian Mark Massa, both Puritans and Anglican Virginians "despite their many differences, shared the fear and hatred of Rome...The settlers themselves had been cradled in an England more bitter against Catholicism 
then than at any other time."1 The Catholic Church was viewed as a political and military force attempting to overthrow the English government and the Church of England. ${ }^{2}$ Historian Robert Lockwood believed that some of these fears stemmed from the November 5, 1605 Gunpowder Plot, a fanatic Catholic plot to bomb Parliament, kill key government officials, and assassinate King James I, which would initiate a Catholic uprising throughout England. The plan was discovered, and officials arrested and tortured Guy Fawkes, one of the conspirators, who revealed the others involved in the plot. Most of the plot organizers were captured and executed. ${ }^{3}$

Prior to the Gunpowder Plot, English anti-Catholic laws were cruel but applied mainly to priests, who were to be executed if they were discovered to be practicing the outlawed faith. The reality, however, was that loyal laity were left in relative peace as restrictions were not strictly enforced. ${ }^{4}$ In fact, many Catholics publically attended Anglican churches but continued to practice Catholicism privately. Those who refused to attend Anglican services could be fined but were often allowed to quietly go about their business. Government officials, however, worried because they feared Catholics were secretly building a military force and would welcome outside assistance from one of the Catholic monarchies of Europe. According to Lockwood, English Catholics were therefore viewed as a "potentially treasonous alien presence.",5 The Gunpowder Plot appeared to confirm these fears and gave the government

\footnotetext{
'Mark S. Massa, S.J., Anti-Catholicism in America: The Last Acceptable Prejudice (New York: Crossroad Publishing Co., 2003), 18.

${ }^{2}$ Ibid.

${ }^{3}$ Robert P. Lockwood, ed., Anti-Catholicism in American Culture (Huntington, Indiana: Our Sunday Visitor, Inc., 2000), 15.

${ }^{4}$ Ibid., 16.

${ }^{5}$ Ibid.
} 
leverage to enforce harsher restrictions. For instance, Catholics could not practice law, hold university degrees, or vote in either local or Parliamentary elections. In addition, they could not serve as officers in the military or possess a weapon. ${ }^{6}$ These anti-Catholic measures found their way into the earliest American communities. Furthermore, the November $5^{\text {th }}$ commemoration of the Gunpowder Plot, known as Guy Fawkes Day, came to the New World with English colonists and was observed with the burning of the Pope in effigy, toasting the overthrow of the papacy, and the singing of anti-Catholic songs. As a result, anti-Catholicism flourished for one hundred and fifty years within British America, ensuring that these ideas would become important facets of American culture. ${ }^{7}$

During the colonial period, Catholics were harassed and discriminated against. Nearly every colony had anti-Catholic laws in their charters and denied Catholics basic civil liberties. ${ }^{8}$ This stemmed from the prevalent belief that the Catholic Church was a foreign presence eager to secure power only for itself. ${ }^{9}$ In 1647 , Massachusetts prohibited priests from entering the colony. ${ }^{10}$ By 1694 , even Maryland passed various anti-Catholic laws including a ban on public mass. ${ }^{11}$ The colony prohibited Catholics from holding public office, carrying firearms, and serving on juries. ${ }^{12}$ Virginia also

\footnotetext{
${ }^{6}$ Ibid.

${ }^{7}$ Ibid., 18.

${ }^{8}$ Clark, "The Bigot Disclosed," 111.

${ }^{9}$ Lockwood, Anti-Catholicism in American Culture, 19.

${ }^{10}$ Massa, Anti-Catholicism in America, 19.

${ }^{11}$ Maryland was founded, in part, as a safe havens for English Catholics escaping persecution in England. Early in its history, the colony adopted a policy of religious toleration. See Robert P. Lockwood, Anti-Catholicism in American Culture, 28.

${ }^{12}$ Massa, Anti-Catholicism In America, 19.
} 
enforced similar restrictions. Even into the early eighteenth century, Catholics still could not vote or hold office in many of the colonies. ${ }^{13}$

The American Revolution alleviated some anti-Catholic sentiment, especially after 1778 when Catholic France entered the war on the side of the Americans. General George Washington issued a decree prohibiting the annual Guy Fawkes Day celebrations in 1775 in an effort to convince Catholic French Canadians to aide the American Revolution. ${ }^{14}$ He described the Guy Fawkes observances as "ridiculous and childish."15 In his general orders, issued on November 5, 1775, Washington stated:

At such a juncture, and in such Circumstances, to be insulting their Religion, is so monstrous, as not to be suffered or excused; indeed instead of offering the most remote insult, it is our duty to address public thanks to these our Brethren, as to them we are so much indebted for every late happy Success over the common Enemy in Canada. ${ }^{16}$

During the Revolution, American Catholics discovered a hero in a Maryland statesman named Charles Carroll. Carroll's career included participation in the Committees of Correspondence as well as the Maryland state senate. He advised the First Continental Congress and sat on the Second. He was one of the wealthiest men in the colonies, and despite the risk of losing everything, he signed the Declaration of Independence and never waivered in his belief that the colonies should be independent. ${ }^{17}$ Carroll stated, "When I signed the Declaration of Independence, I had a view not only of our independence of England but the toleration of all sects,

\footnotetext{
${ }^{13}$ James Hennessey, S.J., American Catholics: A History of the Roman Catholic Community in the United States (New York: Oxford University Press, 1981), 42.

${ }^{14}$ Massa, Anti-Catholicism In America, 19.

${ }^{15}$ George Washington, The Papers of George Washington: 1732-1799, ed. Philander D. Chase (Charlottesville: University Press of Virginia, 1987) 2: 300.

${ }^{16}$ Ibid.

${ }^{17}$ Hennessey, American Catholics, 58.
} 
professing the Christian religion, and communicating to them all great rights." 18 Because of the work of Charles Carroll and other Catholics who supported the American Revolution, anti-Catholicism faded for a time throughout the colonies. ${ }^{19}$ According to Mark Massa, the American Revolution represented a moment when Old World prejudices finally gave way to the creation of a new nation where such prejudices might hold less significance. ${ }^{20}$

Although anti-Catholicism subsided during the Revolution, it did not disappear entirely. By 1787, Catholics still had the franchise in only three states: Delaware, Maryland, and Pennsylvania. ${ }^{21}$ Other states denied Catholics the right to vote as well as the ability to hold office. By the nineteenth century, anti-Catholic feelings simmered under the surface of political and cultural life and resurfaced periodically. By 1830, three hundred thousand Catholics lived in the United States, making up two and one half per cent of the population. By 1860 , that number jumped to three million, or nineteen per cent of the population. Two million of the three million were immigrants, three-fourths of them Irish, predominantly Catholic, many of whom had escaped the potato famine and arrived to the United States destitute. ${ }^{22}$ Violence against Catholics was often directed at the Irish, the largest group of Catholics in the country. Because many of the new arrivals were Catholic, traditional prejudices against Catholics reemerged among some segments of the American population. Complaints against Catholics included the exclusivity of Catholic schools and the inclination of

\footnotetext{
${ }^{18}$ Ibid, 59.

${ }^{19}$ Ibid, 117.

${ }^{20}$ Massa, Anti-Catholicism In America, 20.

${ }^{21}$ Clark, "The Bigot Disclosed," 111.

${ }^{22}$ Ibid., 118.
} 
immigrants, particularly the Irish, to connect with political machines. ${ }^{23}$ During the Antebellum era, the Protestant and Catholic press engaged in intense debates over which Christian church should command the hearts and minds of the American people. ${ }^{24}$ For example, the prominent Protestant minister and president of the Lane Seminary in Cincinnati, Ohio, the Reverend Lyman Beecher, was responsible for some of the most inflammatory anti-Catholic rhetoric of the time. In 1834 , he said, "The Catholic Church holds now in darkness and bondage nearly half the civilized world...it is the most skillful, powerful, dreadful system of corruption to those who wield it, and of slavery and debasement to those who live under it., ${ }^{, 25}$

One issue that fueled the religious debates of the 1830 s was the widespread conviction that Pope Gregory XVI planned to take over the Mississippi Valley as part of a larger plan to gain political control over the United States. Samuel F.B. Morse, the inventor of the telegraph, fueled this fear in a book published in $1834 .^{26}$ The popular work, A Foreign Conspiracy Against the Liberties of the United States, serialized in the New York Observer, discussed concerns over a plot between Rome and the Old World monarchies. ${ }^{27}$ Morse also wanted readers to unite against Catholic parochial schools as well as Catholic office holders. He published a series in the New York Journal of Commerce throughout 1835 that elaborated on these ideas. ${ }^{28}$ In addition, a new anti-Catholic literary genre appeared, the convent horror story, in

\footnotetext{
${ }^{23}$ Hennessey, American Catholics, 118.

24 Ibid., 120.

${ }^{25}$ Ibid., 119.

${ }^{26}$ Ibid, 121.

${ }^{27}$ Massa, Anti-Catholicism In America, 23.

${ }^{28}$ Ibid., 24.
} 
which young women were abused and exploited by priests. Popular examples included Rebecca Reed's tale, Six Months in a Convent (1835), and Maria Monk's Awful Disclosures of the Hotel Dieu Nunnery in Montreal (1836). ${ }^{29}$ This popular genre was a part of a significant anti-Catholic publishing tradition represented by groups such as the American Home Missionary Society and the American Tract Society; both groups published hundreds of pamphlets that claimed Catholics violated the liberties of American citizens by requiring Catholics to adhere to Church doctrine above American democratic principles. ${ }^{30}$

Such literature contributed to anti-Catholic violence. For example, on August 11,1834 , a Boston mob set fire to the Ursuline convent described in Rebecca Reed's account. $^{31}$ The violence stemmed from Reed's public disclosures regarding her time spent at the convent. In addition, respectable Protestant preachers used Reed's story to stir the violence that resulted in the attack. ${ }^{32}$ For example, Reverend Lyman Beecher wrote about Catholic plots for power. He emphasized the role that schools played as centers of indoctrination against American values. In Beecher's book, A Plea for the West, he wrote that Catholic schools were being developed that would undermine the New England public school tradition. ${ }^{33}$ Beecher also embarked on the lecture circuit

\footnotetext{
${ }^{29}$ Hennessey, American Catholics, 121.

${ }^{30}$ Despite questionable information, Maria Monk's book became a best seller and was touted as the furst accurate depiction of convent life. Monk's account was published with funding from several Protestant clergymen, and she traveled the lecture circuit promoting her story. Rebecca Reed's story about her time at an Ursuline convent in Boston sold almost two hundred thousand copies within the first month of its release and was in print for over a century. See Mark Massa, Anti-Catholicism in America: The Last Acceptable Prejudice, 22-23. See Robert P. Lockwood, Anti-Catholicism in American Culture, 31-32.

${ }^{31}$ Lockwood, Anti-Catholicism in American Culture, 30.

${ }^{32}$ Clark, "The Bigot Disclosed," 111.

${ }^{33}$ Massa, Anti-Catholicism In America, 24.
} 
in 1834 , which culminated with three anti-Catholic sermons in Boston that instigated the attack on the Ursuline convent. Beecher stated, "the principles of this corrupt church are adverse to our free institutions, from the contempt and hostility which they feel towards all Protestants." ${ }^{34}$ In addition, Beecher claimed Catholics would "subvert our free institutions and bring into disgrace all ideas of an effective government." 35 Historian Mark Massa described the burning of the Boston Ursuline convent as one of the most important political events in nineteenth century Massachusetts because of the precedent it set for the continuance of anti-Catholic prejudice and the use of violence against Catholics. ${ }^{36}$

These events can be viewed within the wider context of the Second Great Awakening. The revival, which occurred during the early nineteenth century, created a wave of Christian evangelicalism, which, in part, spoke of eliminating the corrupting influences of institutions like the Catholic Church. This movement coincided with rising immigration rates, which brought an increase in cultural diversity to the United States. Ministers such as Beecher often spoke of the corrupting influences they felt inherent in this new cultural diversity.

The momentum of anti-Catholic activism increased when a nativist movement began to influence national politics in the middle of the nineteenth century. The Order of the Star Spangled Banner, an anti-Catholic nativist organization, was founded in the late $1840 \mathrm{~s} .{ }^{37}$ This order, founded by Charles Allen, was a New York City-based group

\footnotetext{
${ }^{34}$ Ibid., 25.

${ }^{35}$ Ibid.

${ }^{36}$ Ibid., 24.

${ }^{37}$ Hennessey, American Catholics, 124.
} 
concerned by ever increasing numbers of Catholic immigrants from Ireland and

Germany. The group wanted to exclude Roman Catholics from public office and even proposed banning Catholics from entering the country. ${ }^{38}$ In May of 1848 , the formation of the American and Foreign Christian Union created a national antiCatholic movement. ${ }^{39}$ The goal of this evangelical Protestant organization was to convert non-believers and Catholics to a "pure" form of Christianity. It successfully fundraised and sent out lecturers and missionaries to immigrant entry places like New York, where newly arrived Irish and German Catholics entered the country in large numbers. Home agents moved around the country hoping to convince Catholics to reevaluate their devotion to a faith increasingly viewed as contradictory to American values. The Union also established an anti-Catholic library in New York and claimed that it was the largest of its type in the world. The organization also sponsored inflammatory speeches that drew substantial crowds. ${ }^{40}$

Groups such as the Order of the Star Spangled Banner and the American and Foreign Christian Union formed the core membership of the Know Nothing political party, which was officially created in 1849 . The Know Nothings often worked behind the scenes to promote nativist and anti-Catholic political candidates. ${ }^{41}$ Many governors, senators, congressmen, and state-level political candidates owed their political success to Know Nothing influence, which was particularly powerful in the

\footnotetext{
${ }^{38}$ Ibid.

${ }^{39}$ Massa, Anti-Catholicism In America: The Last Acceptable Prejudice, 26.

${ }^{40}$ Ibid.

"I Ibid., 27.
} 
Northeast, the border-states, and the South. ${ }^{42}$ The party experienced some success in the 1852 elections, mostly in small, local campaigns scattered through several states. ${ }^{43}$ In June 1854, the Know Nothings sponsored a national convention to create a sense of unity surrounding its fundamental ideals. The political party, in part, promoted itself as a "no Popery" party. This element of the Know Nothing platform accounted for the unity it achieved amongst its adherents when other political parties remained divided over sectional differences based on slavery. ${ }^{44}$ Even if Know Nothings argued over the future of slavery, they achieved common ground through anti-Catholicism. The Know Nothings thrived, reaching the height of their success with the 1854-1855 elections. This can be attributed to growing concerns regarding the increase in Irish Catholic immigrants. These immigrants were portrayed as adversaries to American values, particularly because it was commonly assumed that their primary loyalties were to the Pope in Rome. Nativist political activists pledged to curb immigration, to prevent the election of Catholics to office, and to promote the growth of public education based on Protestant values.

The 1850s remained an uncomfortable time for Catholics in the United States. Confrontations multiplied during this decade. One of the worst incidents occurred in Louisville, Kentucky where many German Catholic immigrants settled. ${ }^{45}$ In April 1855, a Know Nothing mayor took office and stirred nativist feelings that already simmered from a series of anti-Catholic lectures that occurred earlier in the year. With

\footnotetext{
${ }^{42}$ Hennesey, American Catholics, 124.

${ }^{43}$ Massa, Anti-Catholicism In America, 27.

44 Ibid., 28.

${ }^{45}$ Hennesey, American Catholics, 125.
} 
more elections scheduled for August 1855, the Louisville Journal sounded a "call to arms" and stated that citizens needed to "rally to put down an organization of Jesuit Bishops, Priests, and other Papists, who aim by secret oaths and horrid prejudices, and midnight plottings, to sap the foundations of all our political edifices." 46 The situation reached the brink when attempts were made to prevent German Catholics from voting in elections scheduled for August 6, 1855. On that day, also known as "Bloody Monday," riots occurred around the city, claiming the lives of twenty people and wounding hundreds of others in a series of fires. Much of the destruction occurred at the hands of Know Nothing political activists who hired rioters to bolster their ranks. ${ }^{47}$

The Know-Nothing phase of American politics ended with the coming of the Civil War, but despite slavery's dominance over the political scene, scars of the Know-Nothing era lingered. For long thereafter, many in the Catholic community felt alienated from the American mainstream. By and large, however, larger political issues, such as states' rights, slavery, and tariffs, prevailed, and intensely anti-Catholic activity faded with the Civil War and, during Reconstruction, when the national focus shifted somewhat toward reform and the rebuilding of the Union. ${ }^{48}$

Throughout the 1870 s and 1880 s, social and economic changes created by industrialization, financial panics, and rising immigration rates sparked a new growth in nativism. To address these issues, the Catholic Church consolidated their efforts to establish parochial schools, particularly after the Third Plenary Council of Baltimore

\footnotetext{
46 Ibid.

47 Ibid.

${ }^{48}$ Massa, Anti-Catholicism In America, 29.
} 
in 1884, a national meeting of American Catholic bishops. ${ }^{49}$ In 1885 , partly in response to the Third Plenary Council, Josiah Strong, a minister and leader with the Evangelical Alliance, a Protestant ecumenical organization, published Our Country. ${ }^{50}$ Strong warned of the negative effects of recent Catholic immigration on democratic institutions. ${ }^{51}$ He also addressed growing concerns about the intentions of the Pope, contending that the Pope desired political power and required Catholics to blindly follow his political judgment. ${ }^{52}$ Strong believed that such allegiance to the Pope made it difficult for Catholics to be considered true citizens. ${ }^{53}$ The minister reflected the view that the Pope hoped to bring the United States under his control, thus explaining the influx of Catholic immigrants. ${ }^{54}$ As a result, American free institutions were threatened, particularly because a Catholic takeover meant the implementation of Catholic education at the expense of public schools, the protectors of those free institutions. $^{55}$

Josiah Strong's ideas, and anti-Catholicism in general, found a home in Clinton, Iowa, when in 1887, Henry F. Bowers founded the American Protective Association (APA), an organization often cited as a precursor to the resurgence of the Ku Klux Klan during the 1920s. The APA achieved prominence during the late

\footnotetext{
${ }^{49}$ Ibid.

${ }^{50}$ Ibid.

${ }^{51}$ Ibid.

52 Josiah Strong, Our Country, ed. Jurgen Herbst (Cambridge, Massachusetts: Harvard University Press, 1963), 65.

${ }^{53}$ Ibid., 64 .

${ }^{54}$ Ibid., 82.

${ }^{55}$ Ibid., 71.
} 
nineteenth century as an anti-immigrant, anti-Catholic populist movement. ${ }^{56}$

Bowers modeled the APA on the structure of the Masons. In addition, he traveled to various parts of the country lecturing on the "Roman peril.".57 APA members vowed to hire Protestants over Catholics and to vote for Protestant candidates over Catholic candidates in elections. ${ }^{58}$ By the 1890 s, the APA reached the pinnacle of its success after successfully spreading rumors that the Pope had absolved Catholics from all oaths of allegiance to the United States. ${ }^{59}$ In fact, many Protestant Americans were convinced the Catholic Church was a political organization that required allegiance only to the Pope. Therefore, under this view, no Catholic could ever be a good American citizen. ${ }^{60}$ In addition, many were convinced that the Catholic clergy wanted to destroy public schools. In fact, most Catholics and many Protestants wanted religious instruction in schools but wanted it on their terms. Protestants preferred public schools, while Catholics favored the creation of their own parochial schools. However, some Catholic leaders requested public support for denominational institutions, like schools. These requests proved unwise because they often contributed to growing nativist feelings. The APA claimed that Rome demanded American tax funds to expand its schools in order to eliminate public schools altogether. $^{61}$

\footnotetext{
${ }^{56}$ Lockwood, Anti-Catholicism in American Culture, 35. See also Donald L. Kinzer, An Episode in Anti-Catholicism: The American Protective Association (Seattle: University of Washington Press, 1964), 3-57.

${ }^{57}$ Massa, Anti-Catholicism in America, 29.

58 Ibid.

${ }^{59}$ Hennesey, American Catholics, 183.

${ }^{60}$ Clark, "The Bigot Disclosed," 131.

${ }^{61}$ Ibid., 132.
} 
American Catholics were predominantly immigrants and constituted much

of the nation's industrial workforce. As a result, they tended to vote Democratic. ${ }^{62}$

Unfortunately, this support for labor did cause problems for the Church and supposedly provided further evidence of some type of conspiracy on the part of the Church to seek political power within the United States. ${ }^{63}$ The APA, for instance, was the most prolific anti-Catholic organization in operation in the late nineteenth century. ${ }^{64}$ It operated outside of regular political organizations and did not dictate a certain party affiliation, though many of its members were Republicans. The APA hoped to be the voice of all anti-Catholic organizations, and members were instructed to oppose various Catholic political candidates and support anti-Catholic legislation. ${ }^{65}$

By 1893 , APA membership stood at roughly seventy thousand and was mostly centered in towns located in the upper mid-West. ${ }^{66}$ When William Traynor took over the leadership of the APA in 1893, the organization began to take on a more national character. ${ }^{67}$ By 1894 , the APA claimed half a million members, and its speakers traveled around the country addressing crowds of supporters. In particular, the APA attracted unemployed workers when the group claimed it was Catholic immigrants

\footnotetext{
${ }^{62}$ Ibid., 133.

${ }^{63}$ Some charged that the Church would use violence to achieve its goals. This view stemmed from the fact that the labor movement was often connected with the use of violence. For example, the Molly Maguires was a secretive Irish Catholic labor organization connected to violent activity in the Pennsylvania coalmines. In addition, Knights of Labor union leader, Terence Powderly, though nativeborn, was of Irish descent and a Catholic. All of this provided sufficient motivation for the APA. See Malcolm Clark, "The Bigot Disclosed,"131-133.

${ }^{64}$ Ibid., 131.

${ }^{65}$ Ibid., 135.

${ }^{66}$ Massa, Anti-Catholicism In America, 29.

${ }^{67}$ Ibid.
} 
who were stealing their jobs. ${ }^{68}$ Throughout the 1890 s the APA encouraged

boycotts against Catholic merchants and discrimination against Catholic labor, all of this stemming from growing resentment of foreign immigrants. ${ }^{69}$ Financial panics, common throughout the 1890 s, fueled the concerns over rising immigration rates, contributing to the appeal of the APA.

The Catholic Church experienced phenomenal growth during this period due to this immigration. With this growth, the Church insisted on maintaining parochial schools while Protestants preferred secular, state-controlled schools. ${ }^{70}$ As a result, Catholic schools were a strong target of anti-Catholic rhetoric. Catholic schools were viewed as unpatriotic institutions promoting a faith dependent upon foreign allegiance. ${ }^{71}$ Since many new immigrants were also Catholic, the growth in immigration was viewed as evidence that allegiances to foreign powers were growing. The Harvard-educated essayist and poet, John Jay Chapman, in protest over the election of a Catholic as a fellow at Harvard, said, "The outspoken purpose of the Roman Church is to control American education." $" 72$ Since Catholic schools were considered a threat to the public school system emerging in urban centers across the country, any attempt by parochial schools to receive public funding for education was portrayed as Rome trying to undermine the American public school system. ${ }^{73}$ Such concerns prompted Maine Congressman James Blaine to introduce a constitutional

\footnotetext{
${ }^{68}$ Ibid., 30.

69 Ibid.

${ }^{70}$ Hennesey, American Catholics, 183.

${ }^{71}$ Lockwood, Anti-Catholicism in American Culture, 34.

${ }^{72}$ Hennesey, American Catholics, 246.

${ }^{73}$ Lockwood, Anti-Catholicism in American Culture, 34.
} 
amendment in 1876 to prohibit public school money from being used by any school affiliated with a church, the obvious target being Catholic schools. ${ }^{74}$

By the end of the nineteenth century, a number of anti-Catholic outlets pervaded American society. For example, Thomas E. Watson, a prominent Georgia politician, founded Tom Watson's Magazine, a magazine that began by representing Populist views but attracted new readership with a nativist, anti-Catholic focus. ${ }^{75}$ In fact, many anti-Catholic periodicals continued to be published into the early twentieth century. By 1914, more than sixty such publications existed, many of them national weeklies with circulations ranging into the hundreds of thousands. One of the most successful of these works was called The Menace, so named from an editorial published in Tom Watson's Magazine. ${ }^{76}$ Founded in Missouri in 1911 by Wilbur F. Phelps, The Menace published blatant attacks against the Catholic Church. By 1914, its weekly circulation reached 1.5 million. ${ }^{77}$

Once American troops entered World War I, the surge in patriotism inspired continued anti-Catholic sentiments. The large numbers of immigrant groups, many of who opposed the war initially, presented a challenge in terms of uniting public

\footnotetext{
${ }^{74}$ Although the Blaine amendment passed the House, it failed to pass the Senate. It was, however, a popular amendment to many state constitutions. Thirty-one states currently have some version of this legislation on the books, preventing aid to Catholic schools. See Robert P. Lockwood, AntiCatholicism in American Culture, 35.

75 lbid., 36.

${ }^{76}$ Ibid.

${ }^{77}$ In response to the increase in anti-Catholic sentiment, Father John F. Noll established a Catholic publishing house that began republishing excerpts from The Menace with an accompanying Catholic response. Every Catholic pastor in the United States received these responses along with requests to support a weekly newspaper to counteract The Menace. As a result, on May 5, 1912, the first installment of Our Sunday Visitor was released. Eventually, Our Sunday Visitor became the largest national Catholic weekly, and Noll's Huntington, Indiana-based organization became one of the largest publishing houses in the world. See Robert P. Lockwood, Anti-Catholicism in American Culture, 3639.
} 
opinion. Therefore, President Woodrow Wilson authorized the establishment of the Committee on Public Information. Organized by George Creel, the agency attempted to unify American public opinion to support the Allies during the war. According to historian Malcolm Clark, Creel created the "prototype of the modern propaganda machine which pumped half-truths, atrocity stories, calculated hate-mongering, honest-to-God patriotism and pure bilge to a receptive press." ${ }^{, 78}$ An outgrowth of Creel's work was the American Protective League (APL), described as "clandestine super-patriots" with active branches in almost every state. ${ }^{79}$ Formed in 1917 , the APL received approval from the Justice Department, which tried to regulate its activities, though not always successfully. The APL hunted down draft dodgers, guarded industrial facilities and utility plants, and harassed those who even mildly disagreed with the war. The APL abused its power by illegally arresting people, terrorizing union organizers, preventing strikes, and breaking existing labor disputes. The propaganda of Creel and the APL lasted throughout the Red Scare years and into the early 1920s. Though not expressly anti-Catholic, these pronouncements of wartime patriotism fueled the " $100 \%$ American" movement of the Ku Klux Klan by implying that all that was alien and foreign was also detrimental to American society. These views became firmly entrenched in many communities across the nation, which proved increasingly problematic for Catholics because of the prevailing view that their

\footnotetext{
${ }^{78}$ Clark, "The Bigot Disclosed," 149.

${ }^{79}$ Ibid.
} 
allegiances continued to lie with an outside leader, first and foremost, rather than with any desire to maintain and protect American ideals and values. ${ }^{80}$

The Ku Klux Klan reemerged in the World War I era as a formidable organization that promoted anti-Catholic sentiment. This new version of the Klan thrived under the leadership of Colonel William Joseph Simmons out of Atlanta, Georgia. Serving as the Imperial Wizard, he resurrected the Invisible Empire in $1915{ }^{81}$ The new Klan succeeded the one that formed in the wake of the Civil War. ${ }^{82}$ The second Klan differed, however, because it attracted individuals who feared foreigners, socialists, Catholics, and others who appeared to threaten traditional American values. ${ }^{83}$ The "new" Klan appealed to white, native-born, Protestant males and borrowed heavily from the Masons and other fraternal orders in creating a strict organizational loyalty. This included oaths of secrecy, obedience, and fidelity, known as Klannishness. ${ }^{84}$ Interest in the Klan received a boost when D.W. Griffith released "Birth of a Nation" in 1915, a film that sympathized with and glorified the original Klan. The film's popularity prompted newspapers to print movie ads next to Klan

\footnotetext{
${ }^{80}$ Ibid.

${ }^{81}$ Georgia politician, Tom Watson, stirred public opinion against Jewish factory manager, Leo Frank, who was accused of murdering a thirteen year-old employee. Frank's lynching, something Watson openly supported, sparked the revival of the Ku Klux Klan. See Malcolm Clark, "The Bigot Disclosed," 151.

${ }^{82}$ The original Ku Klux Klan was formed during the aftermath of the Civil War by a group of exConfederates who, frustrated by Reconstruction efforts and the occupation of the South by Union troops, intimidated carpetbaggers and blacks running for office. See Mark Massa, Anti-Catholicism in America, 30.

${ }^{83}$ Massa, Anti-Catholicism in America, 31.

${ }^{84}$ The Klan's resurrection was, in part, rooted in novelist Thomas Dixon's work, The Clansman, published in 1905. The novel romanticized the Klan as protectors of Victorian culture and values. Coupled with the editorials by Georgia politician, Tom Watson, The Clansman helped to create interest in the revived organization. See David A. Horowitz, ed., Inside The Klovern: The Secret History of a Ku Klux Klan of the 1920s (Carbondale, Illinois: Southern Illinois University Press, 1999), 2.
} 
recruitment ads. ${ }^{85}$ By 1920 , the Klan was popular in only isolated areas and communities. That changed, however, with social conditions in the wake of World War I when troops demobilized and concerns arose regarding employment opportunities for returning soldiers. ${ }^{86}$ Furthermore, conservative politicians and religious leaders, in particular, feared the demise of traditional American values. In addition, immigration rates, particularly from predominantly Catholic nations, such as Poland and Italy, continued to soar. Post-World War I immigration coincided with economic recession and hard times, which increased the overall fear of the foreigner. Furthermore, growing antiradicalism, symbolized by the Red Scare, fueled concerns about the infiltration of radical political ideologies. As a result, the Klan advocated for native-born white Protestants, a message that resonated with nativists. ${ }^{87}$ Anything deemed as a "foreign influence" seemingly threatened the stability of traditional America. As a result, Catholic denunciations by the Klan escalated. ${ }^{88}$ Over time, the Klan's platform shifted from a strict focus on white supremacy to national nativism.

The Ku Klux Klan received valuable assistance from a start-up public relations firm, the Southern Publicity Association, created by Edward Young Clarke and Elizabeth Tyler. ${ }^{89}$ The partnership launched a recruitment drive early in 1920 that

\footnotetext{
${ }^{85}$ The film, "Birth of a Nation" has been called the first blockbuster movie hit in American popular culture. See Malcolm Clark, "The Bigot Disclosed," 151 and Mark Massa, Anti-Catholicism in America, 31 .

${ }^{86}$ Massa, Anti-Catholicism in America, 31.

${ }^{87}$ David Chalmers, Hooded Americanism: The History of the Ku Klux Klan (Durham: Duke University Press, 1987), 110.

${ }^{88}$ Massa, Anti-Catholicism in America, 32.

${ }^{89}$ Clarke and Young saw the Klan as a potential moneymaker because the nativist climate created incentive for membership drives where the Klan could charge dues, a percentage of which went to the Southern Publicity Association. To ensure success, recruiters received a gratuity based on their recruitment numbers. See Malcolm Clark, "The Bigot Disclosed," 152-153.
} 
helped bring about the resurgence of the organization. ${ }^{90}$ Clarke and Young also trained those who would be traveling recruiters. In addition, Clarke and Young developed lists of target members that included Protestant clergymen, police officers, local officials, politicians, and citizens who had past involvement in similar organizations. $^{91}$ The Klan also recruited among skilled manual laborers and among marginal middle class professions. ${ }^{92}$ These efforts tapped into the emotional climate of a certain section of the American population. That emotional climate included nativism, fear of foreign influences, and concerns that traditional American values were faltering. As a result, from early 1920 through 1921, the Klan added nearly ninety thousand new members, using anti-Catholicism as the major rallying point. ${ }^{93}$ Clarke and Tyler encouraged recruiters to exploit these sentiments when talking to potential new members by revisiting the old prejudices and stories about Catholic motives in the United States. ${ }^{94}$ One such prejudice was that Catholics only expressed loyalty to the Pope. In addition, Catholics supposedly indoctrinated followers to believe in their values at the expense of American values. Clarke and Tyler exploited these concerns and sold the idea that Catholics represented the one group that would never be completely assimilated into American culture. During the 1920 s, the Klan thus became adept at tapping into the rich history of anti-Catholic prejudice, making it a major rallying point for the organization. ${ }^{95}$

\footnotetext{
${ }^{90}$ Clark, "The Bigot Disclosed," 153.

91 Ibid.

${ }_{92}$ Horowitz, Inside The Klavern, 3.

${ }^{93}$ Massa, Anti-Catholicism in America, 31.

${ }^{94}$ Ibid.

${ }^{95}$ Chalmers, Hooded Americanism, 33.
} 
The Klan also successfully portrayed itself as the defender of traditional morality in America. ${ }^{96}$ Klan members policed the moral behavior of the communities they infiltrated and attempted to confront such issues as bootlegging, unfair business deals, marital affairs, and other types of behavior they deemed inappropriate. The Klan felt these constituted proper concerns for the " $100 \%$ American" movement, their effort to cleanse the United States of detrimental foreign influences such as the Catholic Church. ${ }^{97}$ The Klan also supported making federal aid available to public schools; this became one of their major political demands, since education was viewed as the main tool for the promotion of American values. ${ }^{98}$ The Klan argued that one public school system would allow children from diverse backgrounds to come together, to be educated under one set of standards, and to emerge united in their support for American ideals. ${ }^{99}$

The secret order contended that Catholic parochial schools served as training grounds for activities that promoted Catholicism only. Traditionally, the Church encouraged parents to send their children to Catholic schools. Anti-Catholics portrayed this as outright rejection of public schools as inferior to the Church's own institutions. Coupled with this was the concern that public schools neglected teaching the values of citizenship, a condition that needed to be rectified. Klan rhetoric included the idea that Catholics were even to blame for any future decline in the

\footnotetext{
${ }^{96}$ Horowitz, Inside the Klavern, 3.

${ }^{97}$ Klan members promoted devotion to sacrifice, service, unselfishness, purity, and the common people. According to the secret order, the flag, the Constitution, and the Bible stood as symbols for these ideals. See David A. Horowitz, ed., Inside The Klavern, 3.

98 Ibid.

${ }^{99}$ M. Paul Holsinger, "The Oregon School Controversy, 1920-25," Pacific Historical Review, 37 (August 1968): 332.
} 
quality of education coming from public schools because some Catholics had

supported a ban on teaching the Bible. In addition, the Klan accused Catholic teachers working in both private and public institutions of placing little value on the teaching of citizenship, accusing some Catholic teachers of teaching poorly on purpose. ${ }^{100}$ In supporting the school bill, the Klan indicated its belief that public schools were the place that children, particularly immigrant children, could be instructed on American institutions that they were otherwise disconnected from. In teaching national values, public schools promoted social cohesion. In this manner, the Klan was able to promote itself as anti-elitist because public schools encouraged the development of popular democracy, which served as the antidote to class stratification, cliques, and factions. To this end, the Klan worked careful to align itself with popular sentiments that private schools promoted exclusivity and snobbery. ${ }^{101}$ Therefore, the Klan used the idea of compulsory public education as a way to connect the Catholic Church and its schools with undemocratic forces in American society. ${ }^{102}$ The larger issue was the Klan's dislike of cultural pluralism and educational modernism and demonstrated the conflict between the growing professional elite and tradition-oriented society, a group fearful of uncontrollable societal change and moral disintegration. ${ }^{103}$

To distinguish itself from the "first" Klan, the second Klan claimed it wanted no part of illegal vigilantism. The Klan worked diligently to achieve these goals under

\footnotetext{
${ }^{100}$ Robin Huffman, "An Analysis of the Interrelationship Between the Oregon School Law of 1922, the Press of Oregon, the Election of Walter Pierce and the K.K.K.," (Master's Thesis, Portland State University, 1974), 5-6.

${ }^{101}$ David A. Horowitz, "The Klansman as Outsider: Ethnocultural Solidarity and Antielitism in the Oregon Ku Klux Klan of the 1920s," Pacific Northwest Quarterly, 80 (January 1989); 15. 102 lbid., 16.

${ }^{103}$ David A. Horowitz, America's Political Class Under Fire: The Twentieth Century's Greatest Culture War (New York: Routledge, 2003), 35-36.
} 
the leadership of Hiram Wesley Evans, a dentist from Dallas, Texas, who succeeded Colonel William Joseph Simmons as Imperial Wizard of the Klan in 1922. Evans successfully consolidated the organization into a national mass movement. ${ }^{104}$ He did so by disassociating the Klan from its violent history and making it into a centralized political organization and lobbying group. During the Klan's peak years, 1922-1925, it elected seven governors, three United States senators, and infiltrated several state legislatures.

At the local level, the Klan's emphasis on homegrown, traditional American morality and values often translated into boycotts of Catholic businesses and political vendettas against individual Catholics. ${ }^{105}$ Klan organizers instructed recruiters to enter communities, learn about the concerns and issues of those communities, and then offer the Klan as the solution. ${ }^{106}$ That research permitted the Klan to tap into anti-Catholic sentiments prevalent all across the country. New recruits were particularly susceptible to the common story that when sons were born into Catholic families, fathers added rifles and ammunition to the local church arsenal. They also listened with concern to reports that the Pope purchased land on high ground overlooking West Point and Washington D.C. Furthermore, the Klan spread rumors that the two cannon on the lawn at Georgetown University pointed directly at the Capitol. ${ }^{107}$ These stories appeared to prove that Catholic allegiance to the Pope would enable him to one day take outright control over the United States and fueling fears that white Protestant

\footnotetext{
${ }^{104}$ Horowitz, Inside The Klavern: The Secret History of a Ku Klux Klan of the 1920s, 3.

${ }^{105}$ Ibid.

${ }^{106}$ Chalmers, Hooded Americanism: The History of the Ku Klux Klan, 33.

${ }^{107}$ Ibid., 111.
} 
America was under attack. ${ }^{108}$ For example, in a Greenville, Mississippi speech given to start a new Klan chapter, a speaker reminded the audience that Catholic assassins murdered both President Garfield and President McKinley. According to the speaker, churches reportedly stored arms in their basements to use when the Pope decided to invade the United States. ${ }^{109}$ This presentation illustrated the Klan's primary goal of defending society from the Roman Catholic menace by utilizing common stereotypes to set up Catholics as scapegoats. Though Catholics were minorities in most American communities, the Klan's emphasis on anti-Catholicism served to illustrate the depth of the underground nature of the problem. ${ }^{110}$ Therefore, Klan membership grew nationwide. At the same time, Klan propaganda divided communities and roused suspicions regarding the loyalties of citizens. ${ }^{111}$

The Klan tapped into several fraternal organizations as well, finding particular success with the Masons. Klan leadership initially came from the Masons and from ambitious local politicians. Klan membership also had a theological base. Members from many Baptist and Methodist churches formed the backbone of the Klan, and many of the ministers from these denominations, by endorsing the Klan, gave the organization a measure of respectability, and, at times, its leadership. ${ }^{112}$ Conservative members of these religious organizations touted the Klan as the protector of traditional American Protestant values. They added that opposition to Catholics was "an antialienism," an opposition to foreign ideas and people who seemed unlikely to

\footnotetext{
${ }^{108}$ Ibid., 112.

${ }^{109}$ Ibid., 66.

110 Ibid., 67.

111 Ibid.

112 Ibid., 111.
} 
assimilate into mainstream American culture. ${ }^{113}$ Historian David Chalmers has written that old stock Americans "were the nation's dominant majority, but they had a profound persecution complex."114 While their status was not directly challenged by the influx of immigrants, the new generation came from diverse ethnic groups, creating a "rekindled nativism."115 The Catholic organization appeared united and highly organized, posing what seemed a genuine threat to Protestant America. Therefore, conservative Protestants took a defensive stance, and, according to Chalmers, "where the Klan could convince them of, or seize upon, this sense of being an embattled minority, its membership rolls soared."116 Klan leader Colonel William Joseph Simmons echoed this when he said,

The dangers were in the tremendous influx of foreign immigration, tutored in alien dogmas and alien creeds, flowing in from all climes and slowly pushing the native-born white American population into the center of the country, there to be ultimately overwhelmed and smothered. ${ }^{117}$

Catholicism, the perfect example of a foreign dogma, supposedly endangered the American town, whose values were preached from Protestant pulpits. Therefore, the Klan presented itself as the self-appointed protector of small-town, traditional America. ${ }^{118}$ Chalmers wrote, "Most of the things which the Ku Klux Klan stood for and those which it opposed became unified in their focus upon a common enemy, the outsider-alien, as symbolized by the Roman Catholic Church."119 Klan activities

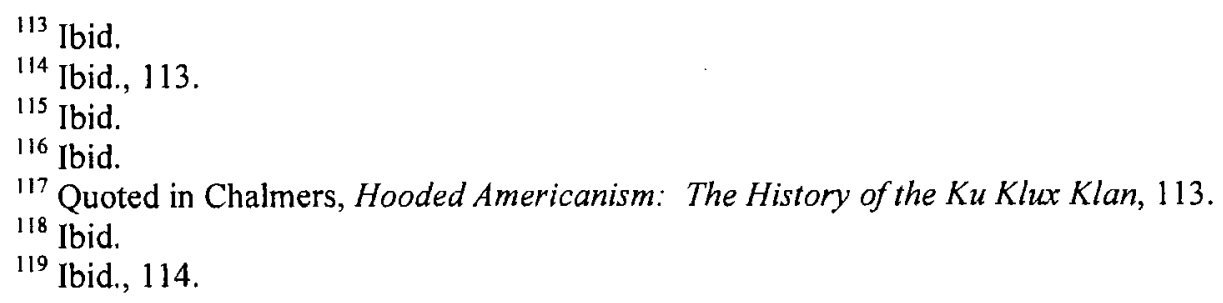


around the country clearly demonstrated these anti-Catholic sentiments, and Oregon was no exception. 


\section{Chapter Two}

\section{A Brief History of Anti-Catholicism in Oregon}

Anti-Catholicism arrived early to Oregon. Catholics and Protestants both hoped to convert the native populations. To that end, Dr. Marcus Whitman, and his wife, Narcissa, arrived in Oregon in 1836. The Whitmans settled among the Cayuse Indians at Waiilatpu near Fort Walla Walla and began their efforts to convert the natives to Christianity. Two years later, in 1838, Catholic priest Francois Norbert Blanchet arrived to begin his work with the natives. This prompted Narcissa Whitman to write, "Romanism stalks abroad on our right hand and on our left and with daring effrontery boasts that she is to prevail and to possess this land." Narcissa Whitman's writings reflected the anti-Catholic sentiments present in American society in the decades prior to the Civil War. ${ }^{2}$ In fact, when Father Blanchet arrived in Oregon Country in 1838 , the Maria Monk story was already circulating. ${ }^{3} \quad$ Early settlers brought their anti-Catholic views with them, including the typical concerns that Catholics were agents of the Pope and advancing his political objectives. ${ }^{4}$ In addition, waves of immigrants, many of them Catholic, arrived to the United States during the 1830 s and 1840s. Throughout the latter half of the nineteenth century, some of those immigrants and their families journeyed to Oregon. Nativists, some of them Christian

\footnotetext{
${ }^{1}$ Hennesey, American Catholics, 133.

${ }^{2}$ Gordon Dodds, Oregon: A History (New York: W.W. Norton and Company, Inc., 1977), 56.

${ }^{3}$ Clark, "The Bigot Disclosed," 111.

${ }^{4}$ Dodds, Oregon: A History, 56.
} 
missionaries, often described these immigrants as uneducated and "uncouth," contributing further to the negative image of the typical Catholic. ${ }^{5}$

Blanchet and his colleagues proved to be ambitious representatives for Catholicism. ${ }^{6}$ For example, Indian agent and missionary, Elijah White, said that Blanchet and his associates "are peaceable, industrious, indefatigable and successful in promoting religious knowledge among the Canadian population and the aborigines of this country."7 Presbyterians, like the Whitmans, and other Protestant missionaries hoped for greater success in converting the natives at the expense of their Catholic counterparts. A competition simmered, therefore, among the Catholic and Protestant missionaries. For instance, in the early 1840 s, Methodist pastor Alvin F. Waller preached to the Clackamas Indians, warning against Roman Catholicism in his sermons. He competed for converts with Father Blanchet, who had the "drama of the Catholic liturgy" on his side. Blanchet's efforts apparently appealed to the Indians more so than Waller's sermons. ${ }^{8}$ Furthermore, the Whitmans were not as successful with the local native population because they tried to convert and civilize tribes by encouraging a more sedentary lifestyle. ${ }^{9}$ The natives grew increasingly disillusioned by the lack of general improvement in their lifestyles and began to doubt there were advantages to assimilating into American culture, particularly since the Protestant missionaries became increasingly connected to attempts to control native lands. ${ }^{10} \mathrm{~A}$

\footnotetext{
${ }^{5}$ Ibid.

${ }^{6}$ Hennesey, American Catholics, 133.

${ }^{7}$ Ibid., 135.

${ }^{8}$ Clark, "The Bigot Disclosed," 109.

${ }^{9}$ Dodds, Oregon: A History, 59.

${ }^{10}$ Ibid.
} 
measles outbreak only served to exacerbate the frustrations of the natives. The Whitman massacre in 1847 , where members of the Cayuse tribe murdered the Whitmans and eleven others, was the culmination of these frustrations. ${ }^{11}$

The Catholic-Protestant relationship in Oregon deteriorated further as a result of the Whitman massacre. ${ }^{12}$ The decline of the relationship was aided by the false stories about the Catholic role in the massacre, told by Oregon pioneers John Smith Griffin, William H. Gray, and Henry Harmon Spalding. ${ }^{13}$ Ironically, a Catholic priest, J.B.A. Brouillet, the first to reach the mission after the massacre, spared Henry Harmon Spalding from death in the aftermath by warning him to stay away from the mission. ${ }^{14}$ Once safe, however, Spalding claimed in a series of articles that he published in the wake of the massacre that the event was the result of a Catholic plan to incite the natives to murder or drive away every Protestant in Oregon Country. ${ }^{15}$ As a result, a bill introduced in the Oregon territorial legislature asked for Catholic expulsion from the region. Although the bill failed, it sent the message that antiCatholic feelings were ever present. ${ }^{16}$ Furthermore, in 1853, Father Brouillet published a response to Spalding's charges called An Authentic Account of the Murder of Dr. Whitman, reopening the debate on the motives for the massacre, and thus, antiCatholic feelings, at a time when anti-Catholicism was growing nation-wide. William H. Gray, in a book that he published in 1870 about the history of Oregon, also

\footnotetext{
"Ibid.

${ }^{12}$ Hennesey, American Catholics, 135.

${ }^{13}$ Clark, "The Bigot Disclosed," 113.

14 Ibid., 115.

15 Ibid., 116.

${ }^{16}$ Hennesey, American Catholics, 135.
} 
promoted the idea that a Catholic conspiracy was behind the Whitman massacre.

Gray's account also fueled anti-Catholic sentiments in Oregon. ${ }^{17}$

In response to the growth of anti-Catholicism in Oregon, two Portland businessmen founded the newspaper the Catholic Sentinel. The paper was founded specifically to be a voice of protest against misconceptions regarding the Catholic faith. Its first edition, published in 1870, discredited Spalding's 1853 account of the Whitman massacre. Spalding published his version of the massacre through the Government Printing Office at taxpayers' expense. Angered by this as well as by the inaccuracies of the account, Portland grocer Henry Herman, and printer J.F. Atkinson, teamed up to publish a four-page broadsheet. ${ }^{18}$ In this first issue of the Catholic Sentinel, Herman wrote that Spalding "succeeded as far as to have his slanderous complaints and false statements printed at the expense of the U.S. Government, thus compelling them, whom he traduces and vilifies, to pay for being thus maligned."19 Since anti-Catholicism and nativism proved to be powerful undercurrents in Oregon society well into the late 1800 s and early 1900 s, the Sentinel continued its efforts to confront false information presented about the Church and its motives.

The June 24, 1880 issue of the Catholic Sentinel revisited the Whitman massacre in part by criticizing the Presbyterian ministers who initially spread the rumors of Catholic involvement. The Sentinel wrote, "In their passion for pelf they stop at nothing. Conscience, truth, honesty and virtue are sacrificed in order that venal

\footnotetext{
${ }^{17}$ Clark, "The Bigot Disclosed," 118.

${ }^{18}$ Wilfred Schoenberg, SJ, Defender of the Faith: The History of the Catholic Sentinel, 1870-1990 (Portland, Oregon: Oregon Catholic Press, 1993), 22.

${ }^{19}$ Catholic Sentinel, April 1, 1871.
} 
avarice and ambition may be gratified." 20 The paper also quoted senator and former general, James W. Nesmith, who arrived in Oregon at the same time as the Whitmans. General Nesmith also refuted the role of Catholics in the massacre saying "I know that Dr. Whitman had cause to dread of the vengeance of the Indians long before it overtook him." ${ }^{21}$ According to the Sentinel, Nesmith expressed these concerns to Dr. John McLoughlin, a prominent Oregon Catholic who ran the Hudson's Bay Company outpost, as early as the spring of 1845 , explaining that given McLoughlin's relations with Catholic missionaries, it would be impossible for him to not know about a Whitman plot. If there had been a plot, Nesmith added, McLoughlin would have been outraged.

The next significant period of anti-Catholicism in Oregon history occurred in the late nineteenth century with the expansion of the American Protective Association into the state. In 1893, APA leader William Traynor traveled through the Western states. In January of 1894, the Portland Telegram was unimpressed with the organization and talked about a meeting of a Portland chapter of the APA, describing it as overly ritualistic. ${ }^{22}$ Despite this, the APA laid some of the foundations for the resurgence of anti-Catholicism in Oregon. Between 1895 and early 1896, the APA experienced its strongest period of growth in Oregon, a period that coincided with strong nativism and concerns over unchecked immigration. While the APA as a

\footnotetext{
${ }^{20}$ Catholic Sentinel, June 24, 1880.

21 Ibid.

22 The APA also claimed 1700 members, and the Telegram took issue with this as well, saying that the numbers were half that amount. The state secretary for the APA, Major H.G. Mathis, even claimed membership numbers at 3100 , again exaggerated figures. See the Portland Telegram, January 25 , 1894.
} 
powerful political organization was short-lived, it did set the stage for the arrival of the Ku Klux Klan. ${ }^{23}$ Oregon, in particular, would prove highly susceptible to Klan propaganda.

Anti-Catholic sentiment continued into the twentieth century, and Oregon reflected this national trend. On-going Catholic immigration into the United States undoubtedly fueled this sentiment, increasing the national outcry for immigration restrictions. ${ }^{24}$ Furthermore, decisions made by the Catholic leadership at this time ensured continued anti-Catholic feelings. For example, while there technically was no national center of Catholic leadership in the country, there was a growing concern amongst Catholics that they needed to be more united in the promotion of Catholic interests. As a result, in December of 1901, the Federation of Catholic Societies met in Cincinnati to attempt the creation of a common standard of beliefs and practices that American Catholics might agree to. Although the Federation operated outside of the political realm, the Catholic Sentinel editorialized on the political possibilities, suggesting that American Catholics consider forming a Catholic Centre Party similar to Germany's, which was created to preserve the Church's independence and rights. ${ }^{25}$ Although an American Catholic political party never formed, anti-Catholicism simmered because of concerns over Catholic bloc voting. Bloc voting during elections fueled nativist concerns that Catholics united together to accomplish political objectives, lending credence to nativist fears that Catholics intended to take over the government of the United States. During this time, however, the Catholic Sentinel,

\footnotetext{
${ }^{23}$ Clark, "The Bigot Disclosed," 139.

${ }^{24}$ Ibid, 141.

${ }^{25}$ Catholic Sentinel, December 5, 1901.
} 
under the leadership of Father Charles R. O'Reilly and then his successor John P.

O'Hara, remained diligent in its efforts to combat anti-Catholicism. For example, the Sentinel continued to warn readers about the surge in anti-Catholicism, particularly during World War I. ${ }^{26}$ During the war, American Catholics, fearing their loyalties would be questioned, unanimously supported the Allied war effort. Once the United States joined the Allies in 1917 , both the Catholic clergy and the press gave solid support for the American war effort. ${ }^{27}$

Despite the efforts of Catholics during World War I, another anti-Catholic organization, the Federation of Patriotic Societies, founded by G. Davidson Buchanan, formed during the war years and became active in Oregon. For example, Buchanan created candidate lists for the May 1916 primary election, providing guidelines for voters. $^{28}$ The Catholic Sentinel published these guidelines in June of 1916.

The Jesuit posing as a labor leader, or a radical, or sometimes as a Protestant clergyman, is an insidious foe. It is such that denounce patriotic utterances as attacks upon 'religion' though they cannot name the day since the Catholic Church was organized in the twelfth century that it has not been in politics as a business...Its adherents... are unfit for any public office wherein they can help the 'great Church' to make America dominantly Catholic. ${ }^{29}$

The Federation of Patriotic Societies continued to grow. In 1917, the Oregon chapter of the Federation was incorporated under the leadership of its secretary, W.C. Elford. The organization considered itself the political arm of Protestant fraternal lodges. ${ }^{30}$ The Federation was not a statewide organization, and it lacked funding. Rivalries split

\footnotetext{
${ }^{26}$ Catholic Sentinel, June 10, 1915.

${ }^{27}$ Clark, "The Bigot Disclosed," 147.

${ }^{28}$ Ibid., 145.

${ }^{29}$ Catholic Sentinel, June 15, 1916.

${ }^{30}$ Clark, "The Bigot Disclosed," 147.
} 
its ranks, so it was never an effective political organization. Its importance, however, was that it kept organized prejudice against Catholics alive, allowing the $\mathrm{Ku}$ Klux Klan to take firm root in Oregon in the early 1920 s. $^{31}$

The first Klan official arrived in Oregon in 1921 from California. Shortly after, Klan leader Major Luther I. Powell swore in the first Oregon Klansman in Medford. Other Klan officials arrived to begin recruitment drives, focusing their efforts in the Willamette Valley where most of Oregon's population of nearly 800,000 lived. ${ }^{32}$ They also worked in smaller communities in eastern Oregon, such as La Grande. Recruitment efforts centered on already established, close-knit groups, such as firemen and policemen, as well as fraternal organizations like the American Legion, the Elks, and the Masons. ${ }^{33}$ While the arrival of the Klan was often greeted with skepticism, by 1923 the Klan had recruited converts all over the state. This growth occurred because while the Klan was new to Oregon, the attitudes and issues exploited by the Klan during the 1920 s were not. ${ }^{34}$

Early twentieth century Oregon was a place of residual anti-Catholicism, nativism, and racism embedded in the earliest settlers who were mainly native-born, Protestant, and white. According to historian Eckard Toy, this narrow population base "reinforced moralistic determination about the cultural imperatives of a chosen people in a promised land." ${ }^{35}$ By 1920, Catholics only constituted 8 percent of Oregon's

\footnotetext{
${ }^{31}$ Ibid., 148.

${ }^{32}$ Eckard V. Toy, "Robe and Gown: The Ku Klux Klan in Eugene, Oregon during the 1920s," in The Invisible Empire in the West: Toward a New Historical Appraisal of the Ku Klux Klan of the 1920s, ed. Shawn Lay (Chicago: University of Illinois Press, 2004), 154.

${ }^{33}$ Ibid.

34 Ibid., 155.

${ }^{35}$ Ibid.
} 
population. In addition, the population was 97 percent white, and 85 percent were native born. As a result, Oregon seemed an unlikely Klan target as well as an unlikely source of a "Catholic problem." And, yet, between 1921 and 1924, Klan membership grew rapidly. As Oregon seemed an unlikely spot for Klan work, the organization in the state moved away from the racial issues that defined its past and focused its efforts in Oregon on education and politics. The Klan refined its approach to address concerns regarding nationalism and the protection of American values against unrestricted immigration and perceived foreign threats. ${ }^{36}$ Oregon, therefore, seemed to be the place to achieve quick success since these issues had long been points of contention for Oregonians.

The Klan also achieved success in Oregon by tapping into fears that society was undergoing uncontrollable and undesirable alterations. For example, Oregonians witnessed the shift from small towns to rapid urbanization, bringing a growing cosmopolitan and modern feel to the state that made it increasingly difficult to achieve social conformity. Many residents tried to protect traditional values while the youth appeared to be a "generation in flux," embracing new standards of behavior and liberal definitions of proper morality. ${ }^{37}$ As a result, the early 1920 s saw an increase in the number of ministers making the lecture circuit, many of whom traveled to Oregon. Often, Klan recruiters would be traveling the same circuit.

These factors partly explain Klan success in Oregon. The Klan, however, also had good timing. Recruiters came to Oregon during a time of economic transition

\footnotetext{
${ }^{36}$ Ibid., 156

${ }^{37}$ Ibid.
} 
within the agricultural and timber sectors. Oregon in 1920 was predominantly an agricultural state. Nationally, however, the farmer struggled because of the decline in farm prices and the loss of export demand after World War I. Oregon was not immune from these national trends in agriculture as evidenced by the increase in farm mortgages. By 1920, half of Oregon farms were mortgaged, up from 33 percent in $1910 .^{38}$ They also tapped into fears brought about by the Red Scare and union activism by organizations such as the Industrial Workers of the World. In addition, concerns mounted over unrestricted immigration, and the Oregon public school system received praise for addressing this by teaching new arrivals the value of American ideas and traditions. ${ }^{39}$ This accounts for the Klan's focus on the elimination of Catholic schools, as these schools were supposedly obstacles to the proper teaching of American ideals and principles because they inherently sought to teach foreign ideas. ${ }^{40}$ These issues created a powerful sales pitch for Klan recruiters. ${ }^{41}$

Furthermore, while there was a cultural and social conservatism in Oregon during the early twentieth century, the state gained a reputation for being politically progressive. The Oregon system, which included the use of the initiative, the introduction of measures directly to voters for their consideration, gave more political expression to the average citizen. According to historian Lawrence Saalfeld, the use of the Oregon system by voters, however, was dangerous for Catholics and for

\footnotetext{
${ }^{38}$ Ralph E. Bunch, "Pierce v. Society of Sisters: The Oregon School Case" (master's thesis, University of Oregon, 1961), 8-12.

${ }^{39}$ Toy, "Robe and Gown: The Ku Klux Klan in Eugene, Oregon during the 1920s," in The Imvisible Empire in the West: Toward a New Historical Appraisal of the Ku Klux Klan of the 1920s, 157.

${ }^{40}$ Lawrence J. Saalfeld, Forces of Prejudice in Oregon: 1920-1925 (Portland, Oregon: University of Portland Press, 1984), 62.

${ }^{41}$ Chalmers, Hooded Americanism, 85.
} 
Catholic schools in particular. ${ }^{42}$ The initiative process potentially allowed a minority to play on old prejudices by allowing citizens to create their own ballot measures. If introduced directly in the state legislature, some of those measures may not have passed, but had potential when delivered directly to voters. ${ }^{43}$ This accounts for the appearance of the compulsory school bill on the 1922 ballot.

According to Eckard Toy, Klan success in Oregon ultimately occurred because the organization made the transition from secret fraternal order to a statewide movement with a political platform to promote. ${ }^{44}$ Luther I. Powell and Klan Grand Dragon Fred Gifford provided effective leadership. Gifford was particularly influential among Portland Masonic groups and was responsible for the Klan's significant involvement in local politics. ${ }^{45}$ The Klan made this shift because it promoted the nativist values that were prevalent in Oregon during the 1920 s. For example, in an interview conducted by C.C. Chapman, the editor of the Oregon Voter, Fred Gifford clarified the political goals of the Klan. The Klan, he said, did not want public affairs controlled by aliens or by "so-called Americans whose primary allegiance is to a foreign power." ${ }^{, 46}$

True to typical Klan recruitment style, the organization looked for a local issue to tap and started in Oregon with the weak enforcement of Prohibition. ${ }^{47}$ Powell recruited over one hundred new members in Jackson County, many of them local law

\footnotetext{
${ }^{42}$ Saalfeld, Forces of Prejudice, 63.

${ }^{43} \mathrm{Ibid}$.

${ }^{44}$ Toy, "Robe and Gown: The Ku Klux Klan in Eugene, Oregon during the 1920s," in The Invisible

Empire in the West: Toward a New Historical Appraisal of the Ku Klux Klan of the 1920s, I59.

${ }^{45}$ Ibid.

${ }^{46}$ Oregon Voter, March 25, 1922.

${ }^{47}$ Chalmers, Hooded Americanism, 85.
} 
enforcement officials. ${ }^{48}$ When the small Medford chapter began the practice of cross burning, politicians in the area jumped on board, despite an anti-mask law passed by the city council banning such displays. ${ }^{49}$ Generally, an "escaped" nun, in the tradition of Maria Monk and Rebecca Reed, would then come out of the woodwork to tell her story, followed by the placement of anti-Catholic literature inside cars and under doors. Then, a Klan lecturer would stir fear of a Catholic takeover, and with the help of a local Protestant pastor, the Klan would win over recruits. ${ }^{50} \mathrm{By}$ following this pattern, within months, the Klan was active in various parts of the state. $^{51}$

The Portland Telegram marked the Klan's arrival in Portland, Oregon on August 21, 1921 when it featured a picture of the King Kleagle, Luther I. Powell, and local officials meeting at the Multnomah Hotel. In an effort to increase recruitment opportunities, the Klan downplayed its violent past and pledged to cooperate with local authorities. ${ }^{52}$ Despite its appeal in smaller communities, Portland provided the Klan's numerical strength. ${ }^{53}$ In particular, Powell successfully tapped into Oregon's Masons. His recruiting partner, P.S. Malcolm, was the sovereign inspector general in Oregon for the Scottish Rite Masonic Lodge. One of the Klan's main recruitment tactics involved gathering membership lists of local fraternal organizations, a task undoubtedly made easier by Malcolm's connections. Masons constituted as much as

\footnotetext{
${ }^{48}$ Ibid., 86.

${ }^{49}$ Ibid.

${ }^{50}$ Ibid.

${ }^{51}$ Ibid.

${ }^{52}$ Clark, "The Bigot Disclosed," 154.

${ }^{53}$ Dodds, Oregon: A History, 197.
} 
60 percent of the Klan's original members in Oregon. ${ }^{54}$ While it remains unclear if Malcolm himself was ever actually a Klansman, he did openly endorse the group, giving the Klan a much-needed sense of respectability within fraternal organizations like the Masons. ${ }^{55}$ In addition, the Klan tapped into nativists concerns over the growing labor movement. Nativists often accused labor unions, which consisted of many immigrants and Catholics, of neglecting the interests of native-born employees. Just when the Klan appeared to be making progress in Oregon, Powell abruptly left the state to visit Atlanta, Georgia. This prompted several newspapers, including the Oregonian, to write that with Powell's departure, the Klan had failed to gain a foothold in the state. Governor Ben Olcott also agreed that the Klan seemed to have left little impression on Oregonians. ${ }^{56}$ This proved to be a serious misjudgment since the purpose of Powell's trip to Atlanta was to secure a charter for the Oregon Klan, a reflection of the Klan's success in recruiting several thousand new members throughout the state. ${ }^{57}$ As a result, the Oregonian, which dismissed the Klan in September of 1921, was forced to reconsider in November after realizing that many of the new converts were politicians gearing up for the 1922 elections. ${ }^{58}$

On December 22, 1921, a substantial crowd gathered at a Klan rally at Portland Municipal Auditorium. They paid fifty cents to see a Klan film and to hear the Reverend Reuben H. Sawyer's lecture, "The Truth About the Invisible Empire,

\footnotetext{
${ }^{54}$ Horowitz, Inside The Klavern, 4.

${ }^{55}$ Clark, "The Bigot Disclosed," 156.

${ }^{56}$ Oregonian, May 15, 1922.

${ }^{57}$ Ibid.

${ }^{58}$ Oregonian, November 5, 1921.
} 
Knights of the Ku Klux Klan."59 The next day, Mayor George Baker announced the creation of a one hundred-member vigilante squad to "augment" the Portland police force. He stated that he would consult various patriotic orders to pick the members, but he worked with the Klan most frequently. ${ }^{60}$ The vigilantes would have their identities concealed. In addition to receiving guns and badges, they would also have the power to arrest citizens. Mayor Baker, because of his political aspirations, was a member of several fraternal organizations, including the Masons, which explained his willingness to work with Gifford and the Klan. Baker never joined the Klan, but the organization did support his campaigns, and thus influenced his political agenda. Therefore, the creation of the vigilante force served as advance payment to the Klan for its future political support. This represented the first of several deals that would make Fred L. Gifford the preeminent political voice of Oregon. ${ }^{61}$ After the November 7, 1922 election, Gifford became the undisputed political boss of the state because so many of the newly elected politicians owed their success to him. ${ }^{62}$ John P. O'Hara, the editor of the Catholic Sentinel from 1903 to 1928, later wrote that, "much has been said of the Ku Klux Klan in Oregon politics, but the forces which carried the bill were operating in the state long before the Klan arrived." Catholic opposition to the Klan when its March 2, 1922 issue censured the organization. The paper stated, "This particular malady seems to recur regularly to

\footnotetext{
${ }^{59}$ Clark, "The Bigot Disclosed," 157.

${ }^{60}$ Ibid., 158.

${ }^{61}$ In 1924, Portland Mayor George Baker ran in the primary for a United States Senate seat. Incumbent Charles McNary won that election. See Malcolm Clark, "The Bigot Disclosed," 158.

${ }^{62}$ Saalfeld, Forces of Prejudice, 37.

${ }^{63}$ Ibid., 61.
} 
plague each generation of Americans. Some genius may yet arise to show a

connection between recurrent phases of anti-Catholic bigotry and the cycle of business changes." 964

Gifford became the most prominent Klan member on the West Coast because of his ability to manipulate local politicians. Fraternal lodges formed the base of Gifford's political organization, and he was able to dominate the Portland political scene. ${ }^{65}$ From his downtown Portland office, he ran Klan affairs. Many also felt that he attempted to run everything else, in Oregon. ${ }^{66}$ As the top Klan leader West of the Rockies, he was prominent enough to intervene in national Klan affairs when it served his interests. ${ }^{67}$ When Luther Powell returned from his trip South with a Klan charter for Oregon, Gifford moved openly into politics, putting pressure on the state legislature to vote according to the Klan's platform. ${ }^{68}$

As the influence of the Klan grew, so did a more open prejudice directed toward Catholics with the introduction and passage of the Compulsory Education Bill of $1922{ }^{69}$ The Scottish Rite Masons initially sponsored the bill. Since many Masons were also Klansmen, the public school initiative helped to further increase the Klan's popularity. ${ }^{70}$ The school bill proposed amending Oregon Law 5259, the compulsory

\footnotetext{
${ }^{64}$ Catholic Sentinel, March 2, 1922.

${ }^{65}$ Chalmers, Hooded Americanism, 88.

${ }^{66}$ Ibid., 87.

${ }^{67}$ Ibid.

${ }^{68}$ Interestingly, there is no record of Gifford being anti-Catholic, probably because his wife was Catholic. His daughters, in fact, attended St. Mary's Academy, a private Catholic girls school located in downtown Portland. See Malcolm Clark, "The Bigot Disclosed," 160.

${ }^{69}$ Saalfeld, Forces of Prejudice, 31.

${ }^{70}$ David A. Horowitz, "Order, Solidarity, and Vigilance: The Ku Klux Klan in La Grande, Oregon," in The Invisible Empire in the West: Toward a New Historical Appraisal of the Ku Klux Klan of the 1920s, ed. Shawn Lay (Chicago: University of Illinois Press, 2004), 202.
} 
education law already on the books. This law required children between the ages of eight and sixteen to attend public schools, but the law allowed for exceptions permitting children to attend private schools. The new bill proposed the removal of the private school exemption and required all children between the ages of eight and sixteen to attend public schools. According to the Klan, private schools represented snobbery, and Catholic schools, in particular, represented a powerful Catholic Church that the Klan believed encouraged corruption and docility. ${ }^{71}$ Public schools, on the other hand, could defend the Klan's " $100 \%$ American" platform, an agenda they hoped to transform into a set of national values. ${ }^{72}$ This platform placed emphasis on English language instruction and included a general effort to preserve American institutions and to oppose any efforts to limit the public school system. ${ }^{73}$ More importantly, the bill struck down the language that recognized both parochial and private schools as acceptable establishments for primary education. ${ }^{74}$ Supporters of the measure stated that the intent of the bill was to aid the assimilation and education of the foreign-born. It planned to utilize public schools as the best venue to absorb all of the prejudices and "narrow views of life" generated by a diverse population, with the ultimate goal being the creation of "true Americans." 75 Oregon was to be the test state for the school measure since the social make-up of the population seemed to

\footnotetext{
${ }^{71}$ Ibid., 203.

72 Ibid., 202 ,

${ }^{73}$ Saalfeld, Forces of Prejudice, 66.

${ }^{74}$ Ibid., 69.

${ }^{75}$ Congress was also debating the Sterling-Towner bill, the first attempt to create a national department of public education. Although this legislation did not pass at this time, it served to highlight concerns regarding public education, concerns held by both Democrats and Republicans. Most politicians understood the need for a national public education system to educate and train the large influx of immigrants that lived in the United States. See Lawrence Saalfeld, Forces of Prejudice, 67-70.
} 
indicate a sure victory at the polls. Klan-sponsored measures were also introduced in states such as Michigan, California, Oklahoma, Washington, and Texas.

By 1922, Democrats and Republicans in Oregon were divided because of the compulsory school bill. The Oregonian reported on the divisiveness saying, "This campaign, the school bill, has caused turmoil in the ranks of both Republicans and Democrats." ${ }^{76}$ That division, however, was especially evident among Republicans. Within the Republican Party, conservative leaders hoped to preserve the status quo by promising to protect traditional American values against the tides of modern change ushered in during the 1920s. In particular, concerns arose over Republican governor, Ben Olcott, and his connections to liberal Democrats. ${ }^{77}$ By the spring of 1922 , Governor Olcott publically opposed the Klan, and as a result, the Klan marked him for political elimination. ${ }^{78}$ The March 30, 1922 edition of the Catholic Sentinel reported on Olcott's announcement that he was running for re-election as Oregon's governor. In doing so, he made a statement on religious liberty saying that his administration was always about all Oregonians, not a select few. He stated, "No secret chains will bind me or my administration to the mandates of an invisible government. The executive office shall not be the puppet of mysterious figures sitting in the background, actuated by motives unknown to the great body of the electorate."79 Olcott promised to protect Oregon's heritage of free religious worship. In the May primaries, however, he faced tough competition from his opponent, fellow Republican

\footnotetext{
${ }^{76}$ The Morning Oregonian, November 2, 1922.

${ }^{77}$ Clark, "The Bigot Disclosed," 162.

${ }^{78}$ Chalmers, Hooded Americanism, 88.

${ }^{79}$ Catholic Sentinel, March 30, 1922.
} 
Charles Hall, who had received the endorsement of the Federation of Patriotic Societies, an organization tied to the Klan that also supported the proposed initiative for public schools. ${ }^{80}$ Therefore, Hall openly endorsed the measure. Hall also acted as a Klan spokesman in the state senate. Historian Lawrence Saalfeld believed these activities also made Hall the main proponent of anti-Catholicism in the public sector. ${ }^{81}$ According to Saalfeld, "Klan commitment to the school bill and hostility toward Olcott brought national attention to the Oregon election of $1922 ., 82$

In May 1922, when the primary elections occurred, anti-Catholic sentiments intensified. For instance, most anti-Catholics, with Klan support, wanted economic, political, and social sanctions in place against the Catholic community. Anti-Catholics also encouraged people to avoid Catholic-owned businesses. Furthermore, antiCatholic Klan supporters also agreed not to hire Catholic employees or to vote for Catholic candidates for office. The Protestant community faced Klan pressure to follow its ideas. Throughout May of 1922, during Sunday services, Klan visitors interrupted eighteen Portland congregations in an effort to generate voter support. ${ }^{83}$ The Catholic Sentinel commented on the Klan's recruitment of Protestant clergy members in its April 13, 1922 edition, saying that a common practice amongst Klan recruiters was to enter churches during services to present financial gifts to the minister. The Sentinel stated, "It appears that many ministers have succumbed to the $\mathrm{Ku}$ Klux advances, though to the outsider it is hard to see what Protestantism has to

\footnotetext{
${ }^{80}$ Clark, "The Bigot Disclosed," 162.

${ }^{81}$ Saalfeld, Forces of Prejudice, 32.

${ }^{82}$ Horowitz, Inside The Klavern, 7.

${ }^{83}$ Clark, "The Bigot Disclosed," 166.
} 
gain by an alliance with the nightie-knights." ${ }^{84}$ The Catholic Sentinel reported on an example of Protestant opposition to Klan activities. In the May 4, 1922 edition of the paper, the Sentinel reported on the Reverend Robert G. Armstrong from Spencer, Massachusetts. At his church, he preached to his congregation on the reasons he elected not to support the Klan. He said,

Join the Ku Klux Klan? The man who does so betrays his real spirit of democracy. Invisible Empire? What does a true American want of an invisible empire? What America wants isn't men who fight under cover, parading in night gowns when they ought to be asleep. If we were to take out of our government the men who, according to the terms of the Ku Klux Klan, are not 100 per cent Americans, the government would collapse for lack of men to handle it. American democracy, American idealism make all men equal. How far a man serves his fellow men depends upon himself, not upon his birth or his religion. ${ }^{85}$

In the same vein, the Sentinel also commented on the increase of Klan-affiliated officials within the justice system. The Sentinel stated, "If the Ku Klux Klan spirit grows it will tend to poison the administration of justice as it will poison other activities of society." $" 86$

Although Olcott prevailed over Hall in the May 1922 primary election, he did so by only a small margin, less than five hundred votes. ${ }^{87}$ Even so, many Catholics mistakenly believed that Hall's defeat signified an end to anti-Catholic rhetoric and, in

\footnotetext{
${ }^{84}$ Apparently, Klan strategies sometimes backfired, at least in Kansas City, Kansas. In its April 27, 1922 edition, the Sentinel published a story about Methodist minister Reverend G. Franklin Ream. During one of his services, three men wearing masks and robes entered the church and offered the reverend a donation. When the men failed to comply with the reverend's request to remove their masks, he returned the donation. See Catholic Sentinel, April 13, 1922 and Catholic Sentinel, April 27, 1922.

${ }^{85}$ Catholic Sentinel, May 4, 1922.

${ }^{86}$ Catholic Sentinel, April 13, 1922.

${ }^{87}$ Chalmers, Hooded Americanism, 88.
} 
particular, the potential of the school bill to pass. ${ }^{88}$ Hall, however, kept the issue alive when he proceeded with allegations of illegal Catholic primary voting in towns such as Mt. Angel and St. Paul, towns with high concentrations of Catholic voters. As part of a larger fundraising effort, fourteen La Grande, Oregon Klansmen donated money for a lawsuit to force a recount, although it was ultimately unsuccessful. ${ }^{89}$ Clearly, the Klan hoped to use the recount as a way to battle the supposed Catholic political machine, and in the process, gain new adherents to Klan ideas. ${ }^{90}$ Olcott also kept the religious issue in the forefront of the governor's race with his anti-Klan proclamation, which the Catholic Sentinel reported on in its May 18, 1922 issue. Olcott stated,

Dangerous forces are insidiously gaining a foothold in Oregon in the guise of a secret society, parading under the name of Ku Klux Klan. These forces are endeavoring to usurp the reins of government, are stirring up fanaticism, race hatred, religious prejudice and all of those evil influences which tend toward factional strife and civil terror. $^{91}$

The paper reported that when the Morning Oregonian asked other gubernatorial candidates their views on the proclamation, some said that the proclamation was used simply for "political effect" while others agreed with Olcott that the Klan was a real issue. For example, Charles Hall, despite being the main Klan-sponsored candidate, said he had seen "no recognizable political activities by the

\footnotetext{
${ }^{88}$ Saalfeld, Forces of Prejudice, 67.

${ }^{89}$ Horowitz, Inside The Klavern, 19.

${ }^{90}$ Saalfeld, Forces of Prejudice, 33.

${ }^{91}$ Catholic Sentinel, May 18, 1922.
} 
Ku Klux Klan." However, Walter Holmes, another candidate, attacked Klan

methods, saying they were a menace to political freedom and public safety. He said,

It tends to intimidate good and efficient men from seeking office, who cannot subscribe to their creed, and without doubt will and does cause hatred and strife between men and women who had heretofore been life-long friends. It has no legitimate business in our body politic, and should be stamped out right now. ${ }^{92}$

Contrary to Hall, Holmes stated he saw evidence that an organized Klan was politically active all over the state. When asked if he was open to Klan endorsement of his campaign, Holmes replied, "No man can do so and believe in the fundamental principles of our government., 93

As part of its reaction to the role of the Klan in the Republican primary, the Catholic Sentinel gave readers a history lesson to make the point that Catholics were not a threat. Despite the long history of anti-Catholicism in America, in noted, the Founding Fathers attended Catholic masses on several occasions over the course of the Revolution as goodwill gestures to their French allies who were essential in securing American victory. The paper also commented that Charles Carroll, as the wealthiest of all the signers of the Declaration of Independence, stood to lose more than anyone in signing the Declaration, a document that he supported as an important step in the granting of equal rights for all Christians in the future. ${ }^{94}$ The Sentinel used these reminders to illustrate the historical significance of such contributions in an effort to

\footnotetext{
92. Ibid.

${ }^{93}$ Ibid.

${ }^{94}$ Ibid.
} 
illustrate the loyalty and patriotism of American Catholics since the beginning of the nation's history.

Moving on to the present, the Sentinel noted President Warren Harding's reaction to the Oregon primary. "There had come to me no other such unwelcome impression as the manifest religious intolerance which exists among many of our citizens," the paper quoted Harding, "I hold it to be a menace to the very liberties we boast and cherish." ${ }^{95}$ The Sentinel also published an editorial on Oregon from the New York World that pictured "a vicious and degrading campaign" in which the state had made "a lamentable exhibition of itself." 96 The World went on to remind its readership that Oregon had a reputation as a progressive state, so it was surprising that practical matters gave way to bigotry, particularly because the Klan stooped low to play on prejudices against Catholics. According to the Sentinel, the Klan "deliberately set about provoking strife throughout the state and capitalizing bigotry and ignorance. There is no place among decent Americans for the spirit of meanness and malice that seeks to set race against race or draw the line according to religious beliefs." $" 97$

Initially, the Ku Klux Klan operated mainly within the Republican Party in Oregon because that party held a large majority over Democrats. Because it was the political party in power, the Klan hoped to tap into Republican special interest connections. In addition, most Irish Catholics voted Democratic, so in Oregon, the state was solidly Republican with Democrats outnumbered nearly three to one. ${ }^{98}$ With

\footnotetext{
${ }^{95}$ Catholic Sentinel, March 30, 1922.

${ }^{96}$ Catholic Sentinel, June 1, 1922.

${ }^{97}$ Ibid.

${ }^{98}$ Clark, "The Bigot Disclosed," 168.
} 
Olcott's victory in the primary, however, Klan leader Fred Gifford surprisingly crossed party lines, endorsed Democrat nominee, Walter Pierce, and promised Klan support in the upcoming election. Pierce agreed to support the public school bill, though he thought it would fail and ultimately cost him votes. ${ }^{99}$ The Sentinel had appeared to see the writing on the wall when it published a letter from a World War I veteran who described Pierce running on a "100\% American" platform with clear directives from the Klan. The author questioned if Pierce would be simply a figurehead while an invisible empire really ran the state. ${ }^{100}$ Catholics held the same rights to call themselves loyal Americans as anyone, he protested, noting that he fought alongside Catholics during the war. ${ }^{101}$ The Sentinel took another line of reasoning when it published an article on the Southern view of the new Klan, stating that some Southerners disliked the new, anti-Catholic agenda of the organization. The paper reported on an incident that occurred at a gathering at the courthouse in Greenville, Mississippi where a Klan organizer gave a speech outlining the dangers of the Catholic Church led by a power-hungry Pope. Leroy Percy, a former U.S. Senator from Mississippi, addressed the crowd at that occasion as well and discussed the positive contributions of three Catholic leaders of the town. Using these leaders as examples, Percy spoke about the absurdity of Klan claims that Catholics hoped to take over. In addition, Percy also spoke of World War I. He said, "I have heard of them

\footnotetext{
${ }^{99}$ Although Pierce feared the loss of votes because of his support for the school bill, he not only endorsed it but also pledged to enforce it should voters approve the measure. See Malcolm Clark Jr., "The Bigot Disclosed," 169 and Robert R. McCoy, "The Paradox of Oregon's Progressive Politics: The Political Career of Walter Marcus Pierce," Oregon Historical Quarterly, 413-415.

${ }^{100}$ Catholic Sentinel, April 6, 1922.

${ }^{101}$ Ibid.
} 
[Catholics] in the hospitals over there nursing the boys, but I did not hear of the Klan over there, and no masks were worn there except gas masks." 102 Percy hoped to demonstrate that the Klan disregarded the fact that all stood together during the war years through many hardships.

Following the Oregon primary, the Sentinel continued to criticize Klan activities. An article in June reported on the activities of Ben Woodhead, the executive head of the Southern Pine Association, a group connected to timber interests in Oregon. Visiting Oregon as a speaker for the Shriners organization, he delivered a talk in which he stated that living conditions in the South had been made nearly intolerable due to Klan activity and its willingness to play upon religious prejudice. "If the K.K.K. evil influence, which in the South has come into the hands of lawless and irresponsible leaders, reaches the Pacific Northwest," he declared, "the people here will know what real troubles are, for the Southern klansism is little else than organized ignorance."103

In contrast to the Sentinel, the Oregonian and most newspapers in the state did not make strong stands against the school bill during the summer and fall of 1922 . Hall Lusk, an attorney who eventually represented the Society of Sisters in its lawsuit against the state and the school bill, described this as "discreet editorial silence" because while the papers commented on taxation and described the personalities of the candidates, they said little on the issues of personal and religious freedom. 104 "It was

\footnotetext{
102 lbid.

${ }^{103}$ Catholic Sentinel, June 15, 1922.

${ }^{104}$ Lusk, The Fight for Educational Freedom, 7.
} 
the American press at its worst," Lusk observed. ${ }^{105}$ "The Catholics of Oregon felt themselves to be, as they were, an outraged and a persecuted people."106

Nevertheless, the September 13, 1922 issue of the Oregonian reported on Pierce's endorsement of the school bill. The paper quoted a signed statement written Pierce that "I did not bring religion into this campaign. I refuse to meet it. It is not the issue."107 The candidate went on to explain that Americans were free to worship as they wished. "It is significant that Mr. Pierce, the democratic candidate, takes occasion now to announce that he is for the bill," the paper commented, "but that the issue is not compulsory education, but taxation, and he will be drawn in no controversy over the former." 108 At the same time, however, the Oregonian noted Pierce's acknowledgement that he was a ninth generation Protestant American, that his wife and her relatives were all Protestants, and that their six children had all received their educations from public schools. "If compulsory education, with its involvement of religious warfare, has no place in the campaign," the paper complained, "why did Mr. Pierce find it necessary to give his sectarian pedigree? What has his Protestantism to do with his candidacy? Disclaiming religious prejudice, and denouncing it, he at the same time makes a bald appeal to religious prejudice," the editorial commented. "Yet religion has no proper place in the campaign. Every candidate knows it, and everyone will disclaim responsibility for it. But it is here, and

\footnotetext{
Ibid.

${ }^{106}$ Ibid., 8.

${ }^{107}$ The Oregonian, September 13, 1922.
}

${ }^{108}$ Ibid. 
the prospect that the public will be able to determine calmly and soberly the issues that concern their material welfare - chief of which is taxation - is not good."109

Throughout the summer and fall of 1922, Olcott, despite his earlier outspokenness, also attempted to remain neutral on the religious element of the election. He avoided mention of the school issue in an effort to avoid antagonizing voters neutral on the issue. However, many conservative Republicans that Olcott counted on for support voted for Pierce instead because of the school bill and Pierce's endorsement of it. Therefore, the school bill fueled traditional anti-Catholic opinions, which were stronger than political affiliations for some voters. ${ }^{110}$ In the end, Olcott lost his bid for re-election in 1922, and Walter Pierce became governor of Oregon. In addition, many other Klan candidates, particularly in Multnomah County, won their elections. ${ }^{11}$ The Klan also secured passage of the school bill with 115,506 voting for the measure, and 103, 685 voting against. ${ }^{112}$ In the wake of the November 1922 election, the state legislature was firmly in Klan control. This meant that anti-Catholic sentiments remained at the forefront of Oregon politics. ${ }^{113}$

\footnotetext{
${ }^{109}$ Ibid.

${ }^{110}$ Saalfeld, Forces of Prejudice, 65.

11 "Clark, "The Bigot Disclosed," 174.

112 Cain, The Oregon School Fight, 4.

${ }^{113}$ Chalmers, Hooded Americanism, 89.
} 


\section{Chapter 3}

\section{The Compulsory School Bill}

The petitions were filed with the Secretary of State on July 6, 1922, and from that time until the election on November 6 the proposed law was the paramount issue in a campaign that for bitterness and acrimony had probably never been equaled in the annals of Oregon. ${ }^{\prime}$

Catholic priest and historian Wilfred Schoenberg wrote that attacks on Catholicism in Oregon by the Ku Klux Klan were part of a larger national campaign. The Klan backed the compulsory school bill in Oregon as a first step to closing all parochial schools in the country. ${ }^{2}$ According to Schoenberg, Oregon was selected because it had the highest percentage of native-born citizens compared to other states. The measure itself was actually the product of a national campaign by the Scottish Rite Masons, with whom the Klan formed a partnership. The Masonic campaign attempted to dilute the strength of Catholic schools by focusing on the development of public schools. The popularity of the school bill reflected certain patterns in Oregon's social and cultural history, such as nativism, 100\% Americanism, and antiCatholicism.

During the early 1920 s, thousands of immigrants continued to arrive in the United States. Oregon nativists were concerned that these immigrants needed to be properly assimilated into American mainstream culture. If those efforts failed, nativists believed that American culture would be saturated with foreign ideas, such as

\footnotetext{
'Lusk, The Fight For Educational Freedom, 3.

${ }^{2}$ Schoenberg, Defender of the Faith, 178.
} 
radicalism and socialism, which they believed contradicted American ideals.

During the 1920s, conservative political and religious groups in Oregon and across the nation worked with a sense of urgency and concern to address this fear. ${ }^{3}$

Nativists viewed public schools as the vehicles of assimilation that would promote American democracy and values while fending off forces that apparently threatened those ideals. ${ }^{4}$ National trends in public education reflected this. For example, in some states the Bible was required reading in classrooms. Furthermore, in several states, most notably Tennessee, the teaching of evolution was illegal, which the Scopes case upheld. This case reflected concerns over the preservation of traditional religious and social values in the face of great change. ${ }^{5}$ In addition, there were numerous attempts to limit the teaching of foreign languages, particularly German. While the impact of these developments varied from state to state, many conservative nativists worried that not all students attended public schools. ${ }^{6}$ In some states, and in particular, Oregon, the compulsory school bill offered the solution.

During the 1922 election, the school bill proved to be the most dramatic issue.

The publicity surrounding the school bill demonstrated that the Klan clearly connected with deep public concerns. ${ }^{7}$ Fred Gifford stated:

We took first place in the eyes of the nation when we put over the school bill. This will be an epoch in state history and a battle long remembered. Many governors and practically all states have wired for a copy of this bill and all literature that helped to put it over. In the

\footnotetext{
${ }^{3}$ David B. Tyack, "The Perils of Pluralism: The Background on the Pierce Case," The American Historical Review 74, no. 1 (October 1968): 74.

${ }^{4}$ Ibid, 75.

${ }^{5}$ State v. Scopes, 152 Tenn. 424, 278 S.W. 57 (Tenn. 1926).

6 Tyack, "The Perils of Pluralism," 75.

${ }^{7}$ Ibid., 78.
} 
very near future this will be a national law instead of a state law. ${ }^{8}$

Private Catholic schools operated, Gifford stated, "for the building of institutions and fostering of ideas contrary to all American ideas."9 Gifford explained the Klan's antiCatholicism as a concern over the Church's institutional power, not the religious practices of everyday Catholics.

We are not against the way the Catholics worship but we are against the Catholic machine which controls our nation. We believe in the separation of church and state and through our public school system we hope to break up their propaganda. ${ }^{10}$

At these schools, Gifford claimed students learned ideas that acted in opposition to Klan beliefs.

Klan support for public schools was influenced by nativist views and wartime patriotism. Yet, fear of immigrants and concern over Americanism was only part of the motivation behind the bill. The resurgence of anti-Catholicism proved to be quite powerful. ${ }^{11}$ For example, Klansmen promoted the view that native-born Americans had the right to control the political and cultural life of the country. The Klan believed that if so-called papists held the majority, they would only support their own beliefs and institutions as dictated by the Catholic Church. ${ }^{12}$ Others expressed concern with the supposed "Roman monopoly" and the fear that children educated in private schools would, as adults, promote un-American ideas and become agents of the Pope.

\footnotetext{
${ }^{8}$ Horowitz, Inside The Klavern, 60.

${ }^{9}$ Ibid., 61 .

${ }^{10}$ Ibid.

11 Tyack, "The Perils of Pluralism," 84.

${ }^{12}$ Ibid., 85.
} 
If this occurred, public schools would be destroyed. ${ }^{13}$ For example, the Oregonian reported that Reverend E.I. Goshen, the pastor of the First Congregational Church of Salt Lake City, spoke in favor of the school measure while visiting Portland during the campaign. He stated, "I do not have to make an appeal nor an apology, just common American citizenship is all that a man needs when he talks for the public schools. The public school is the only meeting place where children can be taught the great principles of Americanism, and be molded into Americans."

In addition, most Oregon Klansmen did not identify with the typical Klan stereotype that connected the organization with rural communities and violent night prowlers. Over half of the Klan's Oregon membership lived in Portland. Many members were blue-collar workers looking to protect their livelihoods and preserve their sense of dignity and importance in the face of a changing society. As a result, the Klan promoted themselves as the protectors of white, native-born, Protestant Americans. They did so by selling the idea that the public school could promote values of importance to that segment of the population, values that included the protection of a fundamentalist morality, white supremacy, strict constitutional interpretation, and the Protestant faith, all defined by Klan standards. ${ }^{15}$

To give voice to public education, the Klan published a pamphlet, written by George Estes, entitled "The Old Cedar School." Estes, a Methodist attorney from Troutdale, wrote the pamphlet as a narrative conversation between an old Oregon pioneer and his children who had chosen to send their children to a parochial school

\footnotetext{
13 Ibid.

${ }_{14}$ Morning Oregonian, November 2, 1922.

15 Tyack, "The Perils of Pluralism," 79.
} 
instead of the public institution. ${ }^{16}$ The pamphlet sought to connect traditional antiCatholic sentiments with concerns regarding the preservation of American democratic ideas in the face of perceived threats from the concentrated power of the Pope and the Catholic Church. ${ }^{17}$ "To have a free people, who do not from day to day depend upon the permission of a divinely anointed Monarch for the right to draw their breath, we must have a people educated in the fundamentals taught in our Public Schools," wrote Estes. ${ }^{18} \mathrm{He}$ continued by explaining that public schools were responsible for our progress as a nation, and therefore, our future depended on them. ${ }^{19}$

Oregon, however, was an unlikely location for the Klan to launch an intense public school campaign because the state appeared to already have a public school monopoly. Ninety-five percent of children ages seven to thirteen were in school, ninety three per cent of them in public schools. ${ }^{20}$ Only one and one half per cent of people ten and older were illiterate, a testimony to the success of public education in the state. The state's largest city, Portland, experienced few of the social problems associated with slums found in many Eastern urban centers. Furthermore, private and public schools had co-existed since the first settlers arrived in Oregon, and there was little antagonism between the two systems. As a result, it would be inaccurate to suggest that private schools were problematic, particularly since enrollment in private schools was on the decline in the early 1920s. Yet, the compulsory school bill issue

\footnotetext{
${ }^{16}$ Ibid., 81.

${ }^{17}$ David Horowitz, "The Klansman as Outsider: Ethnocultural Solidarity and Antielitism in the Oregon Ku Klux Klan of the 1920s," Pacific Northwest Quarterly 80, no. 1 (January 1989): 13.

${ }^{18}$ George Estes, The Old Cedar School (Troutdale, Oregon: Luther I. Powell, Publisher, 1922), 22.

${ }^{19}$ Ibid., 30.

${ }^{20}$ Tyack, "The Perils of Pluralism," 76.
} 
touched a nerve. Father Lawrence Saalfeld suggested this occurred because of the Klan's substantial efforts to exploit traditional anti-Catholic sentiments long prevalent in Oregon. Saalfeld also suggested that while the Klan was the major political force behind the compulsory school bill, eighty per cent of the state's papers never mentioned the connection between the secret order and promotion of the school bill. ${ }^{21}$ In other words, there was apparently no strong condemnation of the Klan's presence or the school bill. This, however, should not be misconstrued as a complete absence of strong opposition. Moreover, the passage of the bill did not represent a decisive victory for the Klan or for nativists. Although Saalfeld and others have argued to the contrary, opposition to the bill existed and was particularly strong. This can be seen even in the origins of the bill itself. ${ }^{22}$

Even though some Masons who supported the bill were tied to the Klan, others felt that the Klan had used the Masonic lodges as a means to an end and had infiltrated the organization to accomplish their political goals. Therefore, it was important to them for the Masons to disassociate themselves from the Klan. ${ }^{23}$ This difference of opinion placed some Masons in difficult positions within their lodges. ${ }^{24}$ The Catholic Sentinel provided insight into the division within the organization when it quoted a Masonic leader in California as asserting that, "the oath of the Ku Klux Klan absolutely subverts everything the Masons are taught as their first and highest

\footnotetext{
${ }^{21}$ Chalmers, Hooded Americanism, 87.

${ }^{22}$ Tyack, "The Perils of Pluralism," 76.

${ }^{23}$ Ibid., 77.

${ }^{24}$ Saalfeld, Forces of Prejudice, 75.
} 
duties. ${ }^{25}$ The paper also reported that several Masonic leaders in Oregon issued similar warnings, including directives to avoid connections with the Klan altogether. ${ }^{26}$ Supporters of the school bill often denied that there was a religious motive behind the bill's origins and accused Catholics of turning the public school issue into a religious debate. ${ }^{27}$ The Klan often suggested that Catholics wanted to destroy public schools, despite the fact that the bill clearly aimed at the abolition of private schools. ${ }^{28}$ Supporters for the bill, in fact, found themselves in difficult predicaments. In some cases, the bill's advocates found that their business associations suffered and that their families became divided as a result of their support for the school bill. ${ }^{29}$ Interestingly, one of the most obvious of these divisions occurred in the political arena. According to attorney Dudley Wooten, "Pierce's leading supporters and committeemen claimed to be opposed to the bill, while those in the Olcott organization, especially in Multnomah Country, were in favor of it." ${ }^{30}$ For example, the Republican executive committee in Multnomah County endorsed the school bill as good Americanism, an unusual move given the fact that the Republican candidate for governor, Ben Olcott, remained neutral and often evaded the issue. ${ }^{31}$ In addition, Olcott adamantly opposed the Klan, which operated frequently within the Republican Party. Another interesting contradiction occurred in the business realm. One supporter found that as he gathered signatures to place the school bill on the ballot, it hurt some businesses to the point

\footnotetext{
${ }^{25}$ Catholic Sentinel, May 18, 1922.

26 Ibid.

${ }^{27}$ Saalfeld, Forces of Prejudice, 71.

28 Ibid., 72.

${ }^{29}$ Ibid., 73.

${ }^{30}$ Ibid.

31 Ibid.
} 
that he stopped working for the campaign. This was due to the fact that many Catholics and others opposed to the bill searched for businesses whose owners also disagreed with the school proposal. As a result, an unofficial economic boycott occurred to counteract the publication of the Klan's " $100 \%$ Directory" of Klansupported businesses. ${ }^{32}$

Many educators at the collegiate level opposed the measure. The Sentinel reported that, "educators of nation-wide reputation have condemned the so-called compulsory education bill to be voted on in Oregon."33 For example, the paper quoted Nicholas Murray Butler, president of Columbia University, who insisted that, "education is primarily and fundamentally a parental and family privilege and duty. This measure is exceedingly dangerous, in that it strikes directly at the authority and dignity of the family." 34 The National Education Association also concurred that parents should have the right to educate children in either private or public schools. ${ }^{35}$ As attorney Hall Lusk wrote,

Educators quite generally denounce it because it puts the education of youth in a straight jacket, makes for a dead level of uniformity and mediocrity, and deprives the public schools themselves of the benefit of that experimentation, which is possible only in privately conducted schools. ${ }^{36}$

Despite such criticisms, Oregon educators avoided confrontation regarding the issue.

The Sentinel questioned this by asking "why our educational leaders in Oregon have

\footnotetext{
32 Ibid., 74.

${ }^{33}$ Catholic Sentinel, October 5, 1922.

${ }^{34}$ Ibid.

${ }^{35}$ Tyack, "The Perils of Pluralism," 82.

${ }^{36}$ Lusk, The Fight For Educational Freedom, 13.
} 
not expressed themselves in regard to a measure which they for the most part condemn., ${ }^{37}$ Some claimed this was because Oregon already had a compulsory education law that ensured children would be educated either in a private or public school. ${ }^{38}$ This absence of confrontation reflected concerns that any opposition to the bill would be perceived as an attack on public schools rather than as a way to simply clarify the existing law. ${ }^{39}$ The Sentinel, again, remained skeptical. The paper wrote, "Two years ago in the Michigan fight when a similar bill was before the electorate of that state, the condemnation of the measure by the public school officials was one of the outstanding features of the campaign." however, failed to use the school bill as an opportunity to define the legal and religious issues surrounding its creation. ${ }^{41}$

Despite this, and claims by some historians that there was little opposition to the bill, letters to the editor of the Oregonian demonstrated that there was a segment of the population that vocalized substantial disapproval. For example, one George King wrote that the school bill was a mean-spirited throwback to other times in history when governments attempted to make citizens think alike. "Not in America," he protested. "No such un-American policy will ever be tolerated in the land of the free. I would like to see an American jury convict a man of the unthinkable crime of judging for himself in matters of religion." ${ }^{42}$ Former Oregon governor Theodore

\footnotetext{
${ }^{37}$ Catholic Sentinel, October 5, 1922.

38 Tyack, "The Perils of Pluralism," 82.

${ }^{39}$ Ibid., 83 .

${ }^{40}$ Catholic Sentinel, October 5, 1922.

${ }^{41}$ Tyack, "The Perils of Pluralism," 83.

42 The Morning Oregonian, November 2, 1922.
} 
Thurston Geer also wrote to the Oregonian saying that the Catholic Church did not undermine support for American ideas, and in fact, the Church included many productive citizens. Because freedom of religious thought was a fundamental right, he added, the school measure needed to be defeated. ${ }^{43}$

Political advertisements in local papers also demonstrated that there was substantial political disagreement on the school measure. For example, the Oregonian ran an ad in support of the measure that reminded voters that "common fellowship is at the very root of all American achievements" and public schools give the viewpoint of the "vast multitude." with patriotism and the promotion of progress. School bill supporters used populist rhetoric to speak about the power of elites and the hope for equal social opportunity. In fact, of the numerous fraternal and social organizations that supported the Klan, one was the Oregon Good Government League, an organization originally formed to challenge the power of corporations. ${ }^{45}$ In addition, Klan propaganda categorized opponents of compulsory public education as either those who believed in the power of the church over the power of the state or those who protected class distinctions. ${ }^{46}$ Public education was portrayed as the avenue to enter into an unequal society. Private institutions undercut the concept of common citizenship that the nation depended on, so, according to school bill proponents, the public school was the appropriate venue in which to blend differences, meaning that American citizenship could not be dependent

\footnotetext{
${ }^{43}$ Ibid.

${ }^{44}$ Ibid.

${ }^{45}$ Kenneth T. Jackson, The Ku Klux Klan in the City: $1915-1930$ (New York: Oxford University Press, 1967), 203.

${ }^{46}$ Ibid., 205.
} 
upon class distinctions. Public schools, therefore, were linked with the creation of an egalitarian society and a classless democracy. Arguably, the Klan's presence in Oregon represented more than simply a white supremacy movement. It was also a populist movement focused on making state and local government more responsive to popular interests while at the same time resisting elite political power. ${ }^{47}$ In contrast, an advertisement against the measure reminded voters that a compulsory school law already existed, and voters needed to be wary of the school measure. The ad suggested that the school bill sought to take away parental control over schooling, a fundamental and sacred right. ${ }^{48}$

The Catholic Church itself was in a quandary over how to voice its opposition to the bill because of the fear that strong reaction against the measure would reinforce popular prejudices about Catholic motives. In fact, attorney Dudley Wooten, who was eventually appointed to lead the Catholic Civil Rights Association, lamented about what he perceived as a growing apathy among Catholics and a desire on the part of some to remain in the background of the school fight since Catholics were clearly the targets of Klan discrimination. ${ }^{49}$ Consequently, the Church worked to counteract the perceived apathy among Catholics by campaigning more earnestly for the measure's defeat. The Sentinel addressed the apathy of Catholics in its June 15, 1922 issue, stating that Catholics had to be "active and fearless in the assertion of our inalienable

\footnotetext{
${ }^{47}$ Robert D. Johnson, "Middle-Class Political Ideology in a Corporate Society: The Persistence of Small-Propertied Radicalism in Portland, Oregon, 1883-1926 (PhD diss., Rutgers University, 1993), 402-445.

${ }^{48}$ The Morning Oregonian, November 2, 1922.

${ }^{49}$ Saalfeld, Forces of Prejudice, 83.
} 
rights." $" 50$ The paper stated that the defense of American constitutional rights was the highest form of patriotic duty, and Catholics should fear not being active enough in the defense of these rights. The paper stated, "The Christian principles which we profess, the schools that we have established, the free exercise of our holy religion and the inviolable rights of Christian parents to educate their children in the perfect system of schooling," stated the paper, were "worthwhile to fight for and if necessary to die for." ${ }^{, 51}$ For a time, though, the Church let others lead the fight. For example, an opposition coalition formed that included Episcopalians, Lutherans, Presbyterians, and Seventh-Day Adventists. ${ }^{52}$ Groups in that coalition included the Lutheran Schools Committee, the Non-sectarian and Protestant Schools Committee, and the Portland Committee of Citizens and Taxpayers. ${ }^{53}$ In reality, opposition to the school bill reflected a variety of interests.

\section{William Wheelwright, the chairman of the Oregon State Child Welfare}

Commission and a prominent Portland businessman, was another outspoken critic of the school bill. In its July 27, 1922 issue, the Sentinel reported that local businessmen,

\footnotetext{
${ }^{50}$ The Sentinel also reported that some Catholic families were deciding against moving into the state of Oregon because of the political climate. The paper stated, "Just for this reason more staunch Catholics ought to settle in Oregon to help in fighting the battles for fair play and religious freedom." See Catholic Sentinel, June 15, 1922.

${ }^{51}$ Ibid.

${ }^{52}$ Chalmers, Hooded Americanism, 89.

${ }^{53}$ Lutheran opposition was particularly strong because it was one of the largest Protestant sects in Oregon and influenced a larger number of votes compared to other churches opposing the measure. They also ran their own private schools, such as Concordia Academy. In addition, Seventh Day Adventists opposed the measure, particularly because they, too, ran private schools of their own. The Catlin, Jewell, Hill, and Cady private schools all publically opposed the bill. Fourteen prominent Oregonians voiced their opposition as members of the Protestant and Non-Sectarian Schools Committee. This group was well organized and reflected a "formidable" opposition. Joseph A. Hill of the Hill Military Academy served as the group's executive secretary. The Hill Military Academy brought suit against the state of Oregon after the passage of the Compulsory School Bill in 1922. See David B. Tyack, "The Perils of Pluralism," 87 and Lawrence J. Saalfeld, Forces of Prejudice, 76-78.
} 
including Wheelwright, submitted an argument in the voter's pamphlet against the school bill. "The argument contends that if the compulsory bill should be passed there would be nothing to prevent the forcing upon all the citizens of a particular religious creed or other obnoxious blue laws," stated the paper. ${ }^{54}$ On September 17, 1922, Wheelwright published an open letter in the Oregonian accusing Klan leadership and Mason supporters of misrepresenting the school bill. ${ }^{55}$ He also confronted sponsors of the bill who denied the bill was religiously motivated and took issue with what he saw as a lack of factual evidence to support the necessity of the bill. He did not see how American ideals were neglected by private schools when they were operated by American churches and staffed by American citizens. He wrote,

For years we have seen young men and women from these private schools bringing to the active citizenship of our state a patriotism and integrity no whit distinguishable from that which characterizes the young people educated in our public institutions. ${ }^{56}$

Wheelwright also disagreed with claims that it was un-American to want to educate children in the faiths of their families. "It is because we are Americans," he wrote, "that we oppose this Bill. It is an invasion of private rights, an invasion of the home and of parental authority." Wheelwright also pointed out the division within the Masons. Even though the organization sponsored the school bill, many within it opposed the proposed law. Wheelwright felt the bill would only encourage further negativity and division:

\footnotetext{
${ }^{54}$ Catholic Sentinel, July 27, 1922.

${ }^{55}$ Saalfeld, Forces of Prejudice, 77.

${ }^{56}$ Oregonian, September 17, 1922.
} 
Now a campaign of intolerance, such as you are making, which would sweep away the hard-won gains of three hundred years, is a crime against Americanism and against Christianity that can never be glossed over by mouth-filling words and unctuous professions of patriotism. ${ }^{57}$

Oregon attorneys represented another significant source of opposition to the school bill. Two hundred lawyers, whose names were listed in a printed statement in the Oregonian, claimed the measure was unconstitutional. ${ }^{58}$ The March 30, 1922 issue of the Sentinel discussed the legal aspects inherent in the passage of the school measure and stated that many of the lawyers who studied the measure felt that it overextended the power of the state. The paper noted that the constitutional issue presented by the school bill was raised two years earlier when a similar measure was introduced in Michigan. ${ }^{59}$ The editors of the Sentinel kept the constitutional issues in the forefront by publishing a brief prepared by some of Oregon's leading attorneys. Published just two weeks prior to the election, the brief attempted to demonstrate how the school bill violated the federal Constitution. ${ }^{60}$ First, the attorneys felt the school bill violated obligations to honor contracts because it would force the closure of private institutions considered corporations under Oregon law. The Sentinel quoted

\footnotetext{
57 Ibid.

${ }^{58}$ The Morning Oregonian, November 9, 1922.

${ }^{59}$ At first, the Secretary of State in Michigan did not put the measure on the ballot because he believed the private schools operated lawfully. Mandamus proceedings, however, forced the secretary to place the measure on the ballot. According to the Sentinel, the Supreme Court in Michigan, at the time of mandamus proceedings, did discuss the constitutionality of the school bill issue. However, the discussion did not center on the actual merit of the measure itself but on the appropriate timing for declaring a measure unconstitutional. Some believed that a measure actually had to be put into effect before constitutionality could be determined. Therefore, the majority of the justices said that the bill should be placed on the Michigan state ballot. The dissenting opinion, however, argued that the Michigan school measure would pit people against each other and create a "bitter religious war." In addition, the dissenters added the measure took rights from parents and gave the state more decisionmaking power on educational matters rather than parents. See Catholic Sentinel, March 30, 1922.

${ }^{60}$ Catholic Sentinel, October 26, 1922.
} 
the brief to the effect that "The corporate right secured by all such organizations may not be impaired by forbidding the exercise of the corporate franchise, without violating the federal constitution." 61 Second, the school bill abridged the privileges and immunities of American citizens. "The state in the exercise of its police power may and should require education, but it is a privilege of the citizen himself to supervise and direct the education so long as it is actually supplied in accordance with the laws of the state," stated the brief. Third, the brief maintained that the owners of private schools would be denied their property without due process of law, and the school bill would deprive teachers in private schools of the right to an occupation. The brief concluded by saying, "The right to regulate the private school exists. The attempt to destroy is arbitrary and oppressive, and therefore abridges the privileges and immunities of the citizen, deprives him of life, liberty and property without due process of law, and is prohibited by the constitution." 62

Lusk, in his work, The Fight for Educational Freedom, argued that the freedom of education was often taken for granted. He wrote that teachers were free to teach as long as what they were teaching was not harmful. He also maintained that parents should be free to select schools for their children. He claimed that "only recently have men begun to assert that freedom of education in American should be destroyed." 63 Lusk felt there were "unmistakable implications" with a school bill that implied that parents had no right to decide on the education of their own children. ${ }^{64}$

\footnotetext{
${ }^{61}$ Ibid.

${ }^{62}$ Ibid.

${ }^{63}$ Lusk, The Fight for Educational Freedom, 1.

${ }^{64}$ Ibid., 2.
} 
Lusk also explored the reasons why the majority of voters approved of the school bill measure. Lusk felt that the clear motive behind the bill was to abolish Catholic schools. The bill masked this intention, however, by proposing that all private schools should be banned. This was done, he wrote, to further the chances that the school bill would pass, as an openly anti-Catholic school proposal was clearly unconstitutional. Lusk added that the campaign for the school bill focused on the concept that public schools were the only vehicle for "true Americanism" because they provided uniform schooling for all children. "The private schools, we were told, were the nurseries of cliques, cults and factions:"

Evil or sinister motives were piously disclaimed. If those opposed to the measure ventured to suggest that its purpose was to interfere with the religious education of Catholic children, they were told that the law was aimed at no particular class or group, and surprise and regret were expressed that anyone should 'inject the religious issue' into the campaign. ${ }^{65}$

Lusk also argued that the title of the school bill misled voters because it implied that Oregon had no compulsory education requirement. "In truth, he wrote, "there had been in effect in Oregon for many years a true compulsory education law requiring all children to attend some school, public, private or parochial." common argument for the bill was the fear that private schools would overtake public schools. Lusk disagreed. "This in a State where the number of children attending private schools was about one-fifteenth of the number attending public schools," he

\footnotetext{
${ }^{65}$ Ibid., 4.

${ }^{66}$ Ibid., 3.
} 
noted ${ }^{67}$ Finally, Lusk described the general climate of the 1922 election as a "well organized and incredibly vicious attack on the Catholic Church [that] went forward by means of speeches, mouth-to-mouth slanders and letters to the press." ${ }^{98}$ He despaired of the resurgence of traditional anti-Catholic sentiment:

All of the old slanders, with which most Catholics are familiar, were revived and put into circulation, while many new ones were invented, some of them so grotesque that it is difficult for those who were not here to conceive of anyone being found so stupid as to believe them. The campaign revealed an appalling degree of ignorance in places where there should have been at least a measure of enlightenment. ${ }^{69}$

Opposition to the school measure also included businessmen who feared that the creation of more public schools would require an increase in taxes. ${ }^{70}$ On the taxation issue, the Oregonian reported that public school facilities were inadequate for the projected growth in enrollment, which would be the result if the school measure passed. $^{71}$ The paper argued that, "any large and unexpected accession of school attendance will put enormous pressure on accommodations and will automatically require general extension of facilities." The Oregonian projected an increase in school growth at somewhere between nine thousand to twelve thousand students. In addition, the paper argued that financial investment in schools would have to keep pace with the student growth rate. To meet this obligation, the paper reported that taxpayers could

\footnotetext{
${ }^{67}$ Ibid., 5.

${ }^{68}$ Ibid.

${ }^{69}$ Ibid., 6.

${ }^{70}$ Tyack, "The Perils of Pluralism," 86.

${ }^{71}$ The Morning Oregonian, November 2, 1922.
} 
see an increase in school spending. ${ }^{72}$ Such reasoning helped the Catholic Church collect diverse allies in its fight against the school bill. ${ }^{73}$

The Knights of Columbus, a prominent Catholic fraternal organization, mounted a particularly strong opposition to the school bill and to the Klan's political platform. When the Sentinel reported on a Klan lecture series in Albany, Oregon, the Knights proposed a follow-up debate where three non-Catholic judges would preside. The Knights hoped to use the debate to challenge Klan allegations on the intentions and motives of the Church. Specifically, the order hoped to dispel myths about the Church, such as the popular belief that the Catholic hierarchy operated as a political machine on the Pope's supposed interest in controlling American politics. In addition, they hoped to challenge the misconception that Catholics opposed public schools. The Klan, however, declined the invitation. ${ }^{74}$

It was the staff of the Sentinel, in the end, that took the lead in opposing the bill. This was in keeping with the paper's long history of calling attention to antiCatholic sentiments. The Sentinel stated that the success of the Klan in America was temporary and that people would not long be fooled by acts based on religious bigotry. ${ }^{75}$ Throughout 1922 , the Sentinel repeatedly criticized the Klan's religious prejudice and devoted large sections of the paper to arguments against the school measure. For example, the Sentinel reported on an incident that occurred on March 22, 1922 in Bend, Oregon between Father Luke Sheehan of St. Francis Catholic

\footnotetext{
${ }^{72}$ Ibid.

${ }^{73}$ Saalfeld, Forces of Prejudice, 75.

${ }^{74}$ Catholic Sentinel, April 27, 1922.

${ }^{75}$ Catholic Sentinel, March 2, 1922.
} 
Church and Reuben Sawyer, a prominent Klan lecturer. At a lecture, Father Sheehan accused the Klan of making false statements about the Church. He was particularly critical of the Klan's accusations that the Pope was trying to control the American government. At one point, men in white robes surrounded Father Sheehan; and when he finished speaking, Sawyer asked Sheehan to leave the premises. ${ }^{76}$

The paper also published Governor Ben Olcott's statement against the Klan with warnings that Klan actions and beliefs threatened the welfare of Catholics. ${ }^{77}$ The efforts of the Sentinel represent a significant voice of dissent against Klan activity in Oregon. For example, after the May 22 primaries and the subsequent attempts by Charles Hall to claim voter fraud, the Sentinel expressed regret that religion entered the election. The Sentinel published a powerful editorial in its May 25, 1922 edition entitled "Let Us Reason Together" that asked Catholic readers to carefully review materials published in the wake of the primaries regarding the school bill measure. "Catholics everywhere in the state earnestly deplore the dragging of religious considerations into the political campaign," it added. ${ }^{78}$ The Sentinel reported that the religious aspect of the primaries was forced upon Catholics due to threats by "secret organizations" against civil liberties. The Sentinel said, "We emphatically deny that any previous activities or organizations of Catholics furnished a cause for those secret organizations of bigotry." The Sentinel went on to dispute the claim that Catholics voted as a united front, saying that Catholics belong to all political groups in public life. Catholics voted as individuals, and Church authorities did not tell voters what

\footnotetext{
${ }^{76}$ Catholic Sentinel, March 23, 1922.

${ }_{77}^{77}$ Saalfeld, Forces of Prejudice, 79.

${ }^{78}$ Catholic Sentinel, May 25, 1922.
} 
political party to vote for, particularly since most Catholics would resent such interference. The Sentinel claimed it was therefore unfair to suggest that Klan prejudice stemmed from the actions of the Church or from the actions of groups such as the Knights of Columbus. ${ }^{79}$ The paper reminded readers that the Knights of Columbus was a forty-year-old fraternal order made up of Catholic men who generally believed it was important to stay out of politics. The Knights' involvement in politics came only with World War I when it went overseas to aide the troops. "Instead of inspiring the organization of secret klans for the destruction of the rights of Catholics," the paper editorialized, "that war record of the Knights of Columbus should have broken down all barriers of distrust and jealousy and forever drowned the voice of Catholic condemnation." 80

The Sentinel used such arguments to question Klan motives, stating that some qualified political candidates were ostracized by the organization and unable to run for office solely because of religion. "If the person is a Catholic," the paper complained, "that is sufficient obstruction and must bring the punishment of denial of the right of preferment for any position." The Sentinel argued that, "some very good newspapers, under the cowardice incident to unknown secret forces, try to convey the idea that 'both sides' are equally to blame," simply because Catholics protested and fought back. The newspaper urged Catholics to vote together when civil liberties were threatened. $^{81}$

\footnotetext{
${ }^{79}$ Ibid.

${ }^{80}$ Ibid.

${ }^{81}$ Ibid.
} 
In an article critical of the Portland Journal, the Sentinel complained that

the Klan "becomes the issue wherever it is allowed to obtain a foothold through the ignorance of the public and the cowardice of the press in failing to expose its sinister intent." other Portland papers have failed in their duty to the public and in the ensuing darkness the Ku Klux Klan has had the mushroom growth of a poisonous fungus when a little sunlight in the way of publicity would have killed it at birth." the editors asked, "that the Journal, like the Oregonian, once fearless and forceful, has likewise become fearsome and decadent, caring more for pocketbook than for principle, and too timorous and pusillanimous to voice its conviction, barters its honor for a mess of klan pottage, lest it lose a subscriber or an advertiser?"84 In an editorial in the September 28, 1922 issue, the Sentinel placed full blame on the press:

Yet we are told that the editors of Oregon are diffident about discussing the matter. It is a curious abdication of the editorial function, apparently because of the fear of losing subscribers. Every editor in Oregon, not blinded by fanaticism, knows that the school measure cannot stand the test of the courts when the guarantee of the citizen's religious and civic rights are invoked against it. ${ }^{85}$

Once proponents placed the school bill on the November ballot, Catholic leaders considered two alternatives. First, the diocese considered remaining passively in the background so as to avoid provoking more anti-Catholic sentiment. Second, it pondered the adoption of a more aggressive approach, placing the religious

\footnotetext{
${ }^{82}$ Catholic Sentinel, August 24, 1922.

${ }^{83}$ Ibid.

${ }^{84}$ Ibid.

${ }^{85}$ Catholic Sentinel, September 28, 1922.
} 
implications of the school bill at the forefront. In the end, the Church based its

fight on the constitutional issues at stake, mainly the belief that the natural rights of parents were threatened. ${ }^{86}$ Father Edwin O'Hara, the Archdiocesan Superintendent of Education and key lobbyist for Catholic education in Oregon, discussed these constitutional implications at an address at the 1922 Marylhurst Summer Session. In arguing against the bill, O'Hara used language identical to that used three years later in the Supreme Court's decision regarding the matter: ${ }^{87}$

We proclaim the following principles: That the family is more ancient and a more fundamental social institution than the state; that to parents belong primarily the right and the obligation of educating their own children; that only when parents fail to do their duty by their offspring had the state a right to interfere; that these rights of parents are primitive and inalienable and may not be violated by the state without injustice; that the rights of parents to educate their children and to choose the instructors for their own offspring is the most inadmissible of human rights, and the exercise by the state of its police power to drag children from the home of parents who are capable of and willing to perform their full duty in the education of their children, would be an importation of tyrannous principles heretofore foreign to American traditions. ${ }^{88}$

By placing emphasis on the school bill's potential violation of fundamental parental rights, O'Hara demonstrated the growing belief among church officials that the primary focus of the fight involved the violation of constitutional rights. ${ }^{89}$

Catholic opposition to the bill was strengthened when Archbishop Alexander Christie became active in the movement. Christie also stressed how the school

\footnotetext{
${ }^{86}$ Saalfeld, Forces of Prejudice, 80.

${ }^{87}$ Ibid., 82.

${ }^{88}$ Catholic Sentinel, July 13, 1922.

${ }^{89}$ Saalfeld, Forces of Prejudice, 82.
} 
measure would undermine the constitutional rights of parents. In a "Pastoral Letter" that appeared in the Sentinel on July 20,1922, Christie petitioned fellow Catholics to oppose the bill. "It behooves you, therefore, to enlighten your nonCatholic friends and fellow citizens on your position on this important subject of Catholic education," he argued. ${ }^{90}$ "The so-called compulsory education bill now pending," he added, "which would deprive citizens of the right to educate their own children in schools according to their religious beliefs and the dictates of their conscience, is aimed at the very heart of the American constitution." 91

Christie proposed the creation of a group, the Catholic Civil Rights Association, which would work specifically for the bill's defeat. ${ }^{92}$ Christie asked attorney Dudley G. Wooten to oversee the organization. ${ }^{93}$ The Association began its work by requesting that each parish, one hundred thirty in total, form two committees, one for men, the other for women. Each committee would canvas its respective community to encourage Catholics to register to vote. They also provided literature to both Catholics and non-Catholics in an effort to clarify the intent and the anticipated impact of the school bill. ${ }^{94}$ The Sentinel celebrated the formation of committees to "undertake a campaign of publicity to offset the attacks, which have been made on the Catholic people of the state and their schools." "The assistance of every Catholic in

\footnotetext{
${ }^{90}$ Catholic Sentinel, July 20, 1922.

${ }^{91}$ lbid.

${ }^{92}$ Saalfeld, Forces of Prejudice, 79.

${ }^{93}$ Ibid., 80.

${ }^{94}$ Ibid.

${ }^{95}$ Catholic Sentinel, July 27, 1922.
} 
Oregon will be sought through the parishes," it explained, "and it is hoped by these means to put the association's literature in the hands of all the voters of the state." 96

The Catholic Civil Rights Association also created a speaker's bureau that sent lecturers around the state. Edwin O'Hara represented one of many priests who spoke repeatedly to their own congregations about the measure. Meanwhile, P.J. Hanley of the Knights of Columbus lectured in many Oregon cities. Dudley Wooten, moreover, traveled to every county in the state and spoke at least once in all of Oregon's major towns. ${ }^{97}$ The Association supplemented its lecture tours with an extensive literature campaign. Wooten's pamphlet, "Twenty-Four Reasons," addressed the main arguments used by school measure supporters. In particular, Wooten confronted what he saw as the bill's overextension of state power. "It is not the principle of toleration merely, which implies privileges conferred or favors granted, that may be abridged or taken away by the State," he argued, "but it is the principle of natural and inalienable right, recognized and secured." 98 The Catholic Sentinel published installments of Wooten's pamphlet in the weeks prior to the election.

The Catholic Defense Guild, an often overlooked, yet critical organization in the fight against the school bill, made further contributions. The Guild worked to educate non-Catholics on the dangers of the bill by providing articles on Catholic education. E.E. Eberhard, the secretary of the Guild, addressed questions regarding the Catholic faith. For example, the Guild ran weekly ads in The Oregonian, The Oregon Journal, The Portland Telegram, and The Portland News from June to

\footnotetext{
${ }^{96}$ Ibid.

${ }^{97}$ Saalfeld, Forces of Prejudice, 81.

${ }^{98}$ Dudley Wooten, Twenty-Four Reasons (Portland, OR: Catholic Civil Rights Association, 1922).
} 
October of 1922 reprinted in the Catholic Sentinel. ${ }^{99}$ The Guild sought to address the misconceptions about the Church that created the anti-Catholicism that fueled support for the school bill. Its work continued after the 1922 election in the form of a new organization, the Catholic Truth Society, that focused on the court fight that followed that year's election. ${ }^{100}$

Organizations such as the Catholic Defense Guild chose wisely when they agreed to work with newspapers like the Portland Telegram. The newspaper had "burned its bridges behind it and definitely come out against the school monopoly bill," the Sentinel observed. The Telegram puts forward its thesis very gingerly and makes reservations about ultimately wanting all children in state schools, but even at that it has more courage than the remainder of the daily press." the school bill, the Telegram contended that the measure involved not just a legal affair but matters of religious and family rights, issues sacred to the average person. The newspaper criticized other papers for putting other issues, such as taxation, at the forefront of the election and criticized candidates from both parties for avoiding discussion on the school bill, an issue far more divisive than taxes. The Telegram was particularly critical of gubernatorial candidate Walter Pierce. While Pierce enjoyed popular support and portrayed himself as an honest candidate, the editors wrote, he "courted the favor of religious bigotry, not because he honestly believed in the methods of these bigots but because he needed their votes." ${ }^{\prime 102}$ In an editorial entitled

\footnotetext{
${ }^{99}$ Saalfeld, Forces of Prejudice, 83.

${ }^{100}$ Ibid.

${ }^{101}$ Catholic Sentinel, October 5, 1922.

${ }^{102}$ Portland Telegram, October 24, 1922.
} 
"Breach Never To Be Closed," the Telegram argued that if the school measure passed, it would be difficult for citizens to forget and move on since its foundation was religious bigotry. Passing the measure would create an environment where it would be difficult to unify Portland on issues requiring public support, it alleged. ${ }^{103}$ "He That Soweth Sparingly," a subsequent editorial, reminded readers of the constitutional implications of the measure and the responsibility of voters to see through bigotry:

What forward looking American is willing to forego for all time the exercise of those sacred privileges of American citizenship-parental choice of schools or the religious freedom of picking a place of instruction where more or less religious training or none whatever may be offered according as he himself and not the state shall dictate? ${ }^{104}$

Despite such efforts, the compulsory public school bill passed in the November 1922 election. Portland attorney Hall S. Lusk observed that, "the Catholics of the whole country justly considered that the Church had been dealt a telling and effective blow. Voters of Oregon had deliberately chosen to abandon those benign principles of liberty which this Government was founded to perpetuate."105 Significantly, the Sentinel predicted "that the friends of private schools will take steps as soon as practicable to test the constitutionality of the school measure." expressed similar opinions. "Of course the bill is unconstitutional under both state and federal laws, and a proper procedure in the courts will no doubt so declare it," Wooten

\footnotetext{
${ }^{103}$ Portland Telegram, October 25, 1922.

${ }^{104}$ Portland Telegram, October 26, 1922.

${ }^{105}$ Lusk, The Fight For Educational Freedom, 8.

${ }^{106}$ Catholic Sentinel, November 9, 1922.
} 
declared. ${ }^{107}$ A week after the election, Archbishop Christie confirmed that a court battle appeared likely. In a statement published by the Sentinel, Christie stated that "the battle against the bill is by no means ended. Plans are being formulated to test immediately the constitutionality of the measure. No rest will be taken until the highest court in the land has rendered a decision."108

The Sentinel also reported on plans to continue the educational campaign to reach non-Catholics regarding Catholic practices and teachings. According to the paper, the program would include the dissemination of Catholic literature, frequent lectures in public halls, and the use of the secular press to print advertisements and to call attention to Catholic activities and charitable works. "The character of the recent campaign against private and parochial schools," the Sentinel warned, "showed how deeply-rooted is anti-Catholic prejudice in Oregon; the election results but confirmed the impression made by the campaign itself."109 The newspaper now vowed to keep the school bill at the political forefront.

In its November 23, 1922 issue, the Sentinel formally announced the creation of the Catholic Truth Society, the organization that would continue to fight the school bill. The Sentinel described the organization as "a patriotic campaign of the highest type" that sought "to dispel animosity from the minds of American citizens, cause them to work together in unity and good will, and thus obviate discord, dissension, religious strife." 110 A week later, the Sentinel announced that one of the first

\footnotetext{
${ }^{107}$ Ibid.

${ }^{108}$ Catholic Sentinel, November 16, 1922.

${ }^{109}$ Ibid.

${ }^{110}$ Catholic Sentinel, November 23, 1922.
} 
endeavors of the Catholic Truth Society was to create a "Catholic Question Box," printed weekly in the Oregonian. ${ }^{11}$ Only one month after the election, the Society established its office headquarters and began receiving inquiries from organizations in other states regarding the advertisements used in local papers to address key questions regarding Catholicism. ${ }^{12}$ The formation of the Catholic Truth Society marked the beginning of the post-election fight to have the school bill declared unconstitutional. For its part, the Sentinel kept the fight alive by printing articles about the Society's activities and by chronicling the court battle. 


\section{Chapter 4}

The Catholic Sentinel and the Challenge in the Courts

As 1922 came to a close, Catholic leaders and press outlets watched the opening of the Oregon state legislature with considerable anxiety. Dudley Wooten,

head of the Catholic Truth Society, set the tone:

Oregon has, indeed, been the prolific mother of freak legislation, explosive demagogy, and reckless iconoclasm in politics and sociology, and her location in this distant corner of the national territory has not exempted other communities from the contagion of her unhealthy radicalism. ${ }^{1}$

Wooten appealed to Catholics to actively participate in repairing the damage:

The sooner Catholics identify themselves with public and political affairs, mingle fearlessly in the interests and rivalries of the community, and forget about their religious preparation while so occupied, the better they will be understood by non-Catholics and the better they will understand the latter. ${ }^{2}$

Most importantly, Wooten believed that the non-Catholic public needed accurate

information regarding the Catholic faith and its practices:

The root of the whole trouble, is a widespread false opinion concerning things and persons Catholic. For 50 years we have permitted so-called 'ex-priests' and fake 'ex-nuns' and scalawags to wander up and down the country, poisoning the public mind against the Church, and in consequence a large percentage of our fellow-citizens entertain false notions concerning us. ${ }^{3}$

${ }^{1}$ Catholic Sentinel, December 28, 1922.

${ }^{2}$ Ibid.

${ }^{3}$ Catholic Sentinel, January 11, 1923. 
Archbishop Christie supported Dudley Wooten's efforts to use the Catholic Truth Society as the vehicle to confront anti-Catholicism with a deluge of information on Catholic doctrine and practices. "We have sufficient confidence in the fairness and justice of great numbers of our non-Catholics," stated Christie, "to believe that their antagonism to our religion and citizenship is not due to malice, but misunderstanding." As historian Lawrence Saalfeld wrote, the archbishop who had spent twenty-three years building the Catholic school system in his diocese, was "determined not to allow his work to be destroyed by a sudden wave of bigotry.",

Christie also asked the Knights of Columbus to select a committee to report on actions of the state legislature that impacted Catholics. ${ }^{6}$ The panel had plenty to report on since anti-Catholics attempted to tap into the momentum generated in the wake of passage of the school bill with more anti-Catholic legislation. The danger became apparent when the Sentinel reported that the Oregon House had passed the Garb Act, a measure that prohibited the wearing of religious habits by Oregon public school teachers. ${ }^{7}$ Republican William F. Woodward, the anti-Catholic head of the Portland School Board, had introduced the bill to the State Senate, where it passed and received the Governor's signature in mid-February 1923.

In the same issue that the Sentinel published a brief passage on the Garb Act, it provided more information on preparations to challenge the new school law. The paper announced that Portland attorneys John P. Kavanaugh, Dan J. Malarkey, Frank

\footnotetext{
${ }^{4}$ Catholic Sentinel, January 25, 1923

${ }^{5}$ Saalfeld, Forces of Prejudice, 88.

${ }^{6}$ Ibid., 38.

${ }^{7}$ Catholic Sentinel, January 18, 1923.
} 
Lonergan, and Hall Lusk would represent Catholic interests in the case and that New York attorney William D. Guthrie would assist. ${ }^{8}$ Though the law was not to take effect until 1926, these attorneys, in cooperation with organizations such as the American Civil Liberties Union, the National Catholic Welfare Council, and the Knights of Columbus, raised funds for the legal battle. ${ }^{9}$ Indeed, Archbishop Christie believed that the constitutionality of the school bill had to be tested in the federal courts because private schools possessed constitutional claims against the state, rather than the state courts where judges might be under Klan influence. In addition, this approach proved more practical than waiting for the law to go into effect in 1926 when irreparable damage might already have occurred to private schools. ${ }^{10}$

Christie began the process of legal redress shortly after the election. On November 22, 1922, he called a meeting of bishops in Seattle, where they unanimously agreed to fight the school law on constitutional grounds. ${ }^{11}$ Christie also kept the court fight on the national barometer. For example, he requested financial assistance from the National Catholic Welfare Council. The group complied, pledging to raise funds to fight the court battle. ${ }^{12}$ The Sentinel reported that the pledge was intended "to extend all the moral, spiritual and financial aid required to test the validity of the law in the state and federal courts and to use every legitimate means to secure its repeal."13 The council warned that, "this legislation directly affected the

\footnotetext{
${ }^{8}$ Ibid.

9 Tyack, "The Perils of Pluralism," 92.

${ }^{10}$ Saalfeld, Forces of Prejudice, 90.

11 Ibid., 89.

${ }^{12}$ Ibid.

${ }^{13}$ Catholic Sentinel, January 25, 1923.
} 
freedom and vital interests of all education in private schools and academies all over the country; especially in the schools where religion is taught as a basic principle or fundamental study." "If the supreme court gives a decision affirming the parental right of education in which we believe," the council proclaimed, "then the case is settled for every state in the union. As a movement to imitate the Oregon law has already spread to several other states and threatens to spread still farther, it is necessary to act quickly and to endeavor to prevent great damage to our schools." The Knights of Columbus also pledged national board financial support.

While organizers laid the groundwork for the court battle, the Sentinel kept the issue alive in the press. One tactic was to discredit the Ku Klux Klan and its efforts in the Oregon state legislature. For example, the Sentinel began reporting in February 1923 that the Klan was losing influence over legislators, and that state legislators appeared focused on constructive legislation than religious matters. "There has been a vast change in public sentiment since the political campaign which ended last fall," it reflected, "and that change is reflected in the course which both houses have adopted since a few days after the session opened." "Governor Pierce is harassed day and night by a small army of seekers after appointments, the most insistent being the $\mathrm{Ku}$ Kluxers who supported him with a vision of the loaves and fishes, the newspaper observed. "They have thronged the corridors of the capitol every hour and are

\footnotetext{
${ }^{14}$ Ibid.

${ }^{15}$ Catholic Sentinel, February 8, 1923.

${ }^{16}$ Catholic Sentinel, February 1, 1923.
} 
howling with hunger." ${ }^{\prime 7}$ The Sentinel complimented legislators for rising above the pressures placed upon them by Klan lobbyists:

Notwithstanding the presence of a large lobby every day since the legislature started, threatening and bull-dozing members in the interest of radical measures, a large number of members in both houses refused to be led by the Kluxers and their allies and even in the lower house, where they were supposed to have a majority, several of their bills were decisively defeated, the remainder receiving similar treatment in the senate. It is a sure sign of returning sanity in Oregon. ${ }^{18}$

In contrast, the Sentinel suggested that Catholics

are asking no favors; are not bothering the legislature with special pleading and are interesting themselves only in behalf of justice and honest effort for the development of the state along the lines that will make for progress and for the state's prosperity, while on the other hand the lobby is filled with $\mathrm{Ku}$ Kluxers clamoring for bigoted action and demanding jobs without regard to fitness or adaptation. $^{19}$

To keep the school bill at the forefront, the Sentinel allowed Dudley Wooten, executive secretary of the Catholic Truth Society, to write about the activities of the group in several installments. The first called Catholics to action. "Today even our staunchest advocates of 'watchful waiting' realize that this policy of silence has been pernicious, and fraught with disastrous results," wrote Wooten. He continued, saying, "The Church is still divine as it ever will be, but the public mind today in Oregon is fairly saturated with anti-Catholic hatred, methodically inculcated into it by the

\footnotetext{
17 Ibid.

${ }^{18}$ Catholic Sentinel, February 22, 1923.

${ }^{19}$ Catholic Sentinel, February 8, 1923.
} 
enemy." "And so the one definite and certain remedy," he concluded, "is a campaign of education, sanely, safely, but courageously and persistently followed up."20

In the next installment, Wooten wrote of the importance of the systematic distribution of literature "to off set the scurrilous, immoral sheets and publications with which the state is flooded."21 The third discussed the importance of publicity and the necessity of correcting misconceptions about Catholics. "Catholic news items and activities should be given to the public press," insisted Wooten. "We should take the public more into our confidence by letting them know more about us."22 A fourth installment reiterated this idea, suggesting that public lectures would do much to correct the falsehoods about Catholics and their intentions. "In view of the constant stream of pernicious falsehood which anti-Catholic speakers disseminate," wrote Wooten, "it is absolutely necessary that we use the platform in order to counteract some of the poison which these have instilled into the public mind." ${ }^{, 3}$ In the fifth installment, Wooten described correspondence with non-Catholics posing commentary and questions regarding Catholicism, which originated from the question boxes placed in the Oregonian.

Wooten informed Sentinel readers that the Catholic Truth Society made it a mission to personally respond to all inquiries by writing letters and sending literature. "Thus personal correspondence with inquirers," he wrote, "will be a powerful means

\footnotetext{
${ }^{20}$ Catholic Sentinel, February 15, 1923.

${ }^{21}$ Catholic Sentinel, February 22, 1923.

${ }^{22}$ Catholic Sentinel, March 1, 1923.

${ }^{23}$ Catholic Sentinel, March 8, 1923.
} 
of bringing the truth before the general public and counteracting the unscrupulous campaign of falsehood and slander engaged in by the enemy."24 Wooten concluded by telling readers that the actions of the Truth Society served as the antidote to criticisms that the Catholic Church was unpatriotic. "In a great country like ours," he concluded, "whatever aids in removing antagonism and hatred and assimilates the various elements in our population, is of the highest importance. Not merely religion and education, therefore, are promoted by the Catholic Truth Society, but the highest form of true patriotism.",25

As the court hearing became imminent, the Sentinel kept readers informed on the process. To that end, the newspaper reported on a U.S. Supreme Court case out of Nebraska that the staff believed to have major implications for the Oregon school law. The statute in question sought to prevent the teaching of foreign languages in elementary schools. Attorney William Guthrie, who assisted on the Oregon school law case, presented a brief to the U.S. Supreme Court in an effort to demonstrate that both the Nebraska and the Oregon laws were similar in nature, and, therefore, both unconstitutional. As it appeared in the Sentinel, quoted Guthrie argued as follows:

It has, however, been urged in the course of this controversy that the police power of a state over the education of minors is virtually unlimited; that a state may make education its own exclusive monopoly, and that it may prohibit any instruction of children in addition to the studies prescribed by it for all. With these contentions we most earnestly differ. ${ }^{26}$

\footnotetext{
${ }^{24}$ Catholic Sentinel, March 15, 1923.

${ }^{25}$ Ibid.

${ }^{26}$ Catholic Sentinel, March 8, 1923. Police power is the ability of state governments to override individual property rights in order to maintain minimal standards of health, safety, and welfare of the people. See Melvin I. Urofsky, A March of Liberty: A Constitutional History of the United States (New York: McGraw-Hill, Inc., 1988), 324-326.
} 
The brief also reminded the Court of Klan to pass school laws similar to Oregon's in states such as Michigan and Washington. ${ }^{27}$ Therefore, the Oregon case could determine the fate of the entire American educational system. For its part, the Sentinel reported on Guthrie's brief to keep the court fight alive in the press and to give Catholic readers hope that the Oregon law would not hold up in the end. Oregon Catholics, therefore, must have been pleased to learn in June 1923 that the Supreme Court had struck down the Nebraska statute. In the majority opinion, Justice James McReynolds stated that the Fourteenth Amendment

denotes not merely freedom from bodily restraint, but also the right of the individual to contract, to engage in any of the common occupations of life, to acquire useful knowledge, to marry, establish a home and to bring up children, to worship God according to the dictates of his own conscience, and generally to enjoy those privileges long recognized by common law as essential to the orderly pursuit of happiness by free men. ${ }^{28}$

The Sentinel reported that the decision was of particular importance to Oregonians because it gave some indication of how the Court might rule in the Oregon school case. J.P. Kavanaugh, an attorney who represented the Society of Sisters, a Catholic organization responsible for the administration of several private schools, stated that the Supreme Court appears, from press reports, to have decided that the right of parents to direct the education of their own children is a fundamental right, a right which cannot be invaded without violating the provisions of the federal constitution. If it be an invasion of that right to prevent the parents from teaching their children a foreign language in a private school, it would certainly be an invasion to

${ }^{28}$ Meyer v. Nebraska, 262 U.S. 390 (1923). 
abolish the private school entirely. ${ }^{29}$

The following month, the Sentinel reported that the Hill Military Academy had filed a complaint in federal court against Governor Walter Pierce and other state officials in an effort to prevent them from enforcing the Oregon school law. ${ }^{30}$ While the Hill Academy suit avoided the religious issue, the Sentinel reported that J.P. Kavanaugh, in representing the interests of Catholic schools, would file a separate suit that confronted the religious implications of the bill. ${ }^{31}$ On August 22, 1923, attorneys for the Society of the Sisters of the Holy Names of Jesus and Mary filed such a lawsuit requesting a temporary injunction to prevent the enforcement of the law. The Sentinel outlined the main arguments presented by lead attorney, J.P. Kavanaugh.

Kavanaugh's brief stated that the Society of Sisters had operated since 1880 as a legitimate corporation under Oregon law and maintained private religious schools around the state in compliance with the state's standards of instruction. ${ }^{32}$ The lawsuit, he argued, centered on the question of whether or not the state had the power to establish a monopoly in elementary education. ${ }^{33}$ Furthermore, the Society contended that the school law was a violation of both parent and teacher liberties because the law sought to deprive parents of the right to control the education of their own children and to deprive teachers of the right to provide that education. ${ }^{34}$ Finally, the Society argued that the compulsory school law violated the religious freedom of Catholic

\footnotetext{
${ }^{29}$ Catholic Sentinel, June 7, 1923.

${ }^{30}$ Tyack, "The Perils of Pluralism," 92.

${ }^{31}$ Catholic Sentinel, July 12, 1923.

${ }^{32}$ Catholic Sentinel, August 23, 1923.

${ }^{33}$ Lusk, The Fight for Educational Freedom, 8.

${ }^{34}$ Saalfeld, Forces of Prejudice, 90.
} 
parents and their children. In the complaint, the Society's attorneys claimed that the private schools were already suffering from the repercussions of the school law, even though it was not to go into effect until September 1, 1926. The complaint stated that state declarations of intent to enforce the law on the required deadline were already causing problems for the Society because "patrons of its schools are already seeking schools in other states and [the] plaintiff is prevented from carrying out the extensive improvements required by the normal development of its schools. " ${ }^{35}$ The strongest argument, however, was the contention that the school measure violated the property protections guaranteed by the Fourteenth Amendment. Attorney Hall Lusk said, "The whole contention for the law was based upon an assertion of the overweening powers of the State to enact legislation that the majority considered to be for the advantage of the State. Persons of this country have a natural right to engage in the business of conducting private schools."

While Oregonians waited for a hearing date to be set, the Catholic Sentinel continued calling attention to anti-Catholicism and the activities of the Ku Klux Klan. For example, the Sentinel editorialized about Portland Mayor George Baker's announcement that he was a candidate for the Republican nomination for United States senator. The paper reported that Baker's political platform was the same as the

\footnotetext{
${ }^{35}$ Catholic Sentinel, August 23, 1923.

${ }^{36}$ Lusk, The Fight For Educational Freedom, 10. Historically, the guarantee of due process protected citizens from arbitrary punishment at the hands of the government. For example, if accused of a crime, a person has the right to counsel and to hear the nature of the accusations against him. Basically, if the government was to deprive someone of liberty and property for committing a crime, it had to follow a certain protocol to do so. The due process protection of the Fourteenth Amendment guarantees a broader extension of due process. This meant that under no circumstances could the government, particularly the legislative branch, deprive someone of property. See Alfred H. Kelly, Winfred A. Harbison, and Herman Belz, The American Constitution: Its Origins and Development, Volume II (New York: W.W. Norton and Company, 1991), 387-388.
} 
Klan's and claimed that Baker merely worked with the Klan to achieve his political ambitions. The Sentinel contended that should the school bill be struck down before the senatorial race, Mayor Baker's campaign would lose momentum:

The business community in Oregon has had about enough religious prejudice to last it for some years and it would not be surprising if the mayor were to find that much of the support which has been his in the past has been lost through his efforts to capitalize ku klux bigotry. ${ }^{37}$

In contrast, the Sentinel reported on another senatorial candidate, C.N.

McArthur, who unlike candidates in the previous election openly denounced the Klan's endorsement and the leadership of Fred L. Gifford. The newspaper reported McArthur's statement that "In common with thousands of other citizens of my native state, I feel that Gifford's power as a political boss should be broken and that his $\mathrm{Ku}$ Klux Klan machine should be relegated to the political scrap heap."38 The Sentinel asserted that the Klan had split into several factions by the end of 1923 , pointing to the fact that the king kleagle of the Northwest, Luther I. Powell, had criticized Oregon Grand Dragon, Fred L. Gifford. According to Powell, Gifford had become "a political autocrat running a steam roller over 'the free thinking minds of real Americans and Klansmen',"39 The paper described Powell's call for Gifford's removal on the basis that the latter was "a pro-Catholic political autocrat who rules his subjects with an iron hand and his royal court of ward politicians. ${ }^{, 40}$

\footnotetext{
${ }^{37}$ Catholic Sentinel, September 14, 1923.

${ }^{38}$ Catholic Sentinel, October 25, 1923.

${ }^{39}$ Catholic Sentinel, November 29, 1923.

${ }^{40}$ Ibid.
} 
In its December 20, 1923 issue, the Sentinel reported that the complaint

filed by the Hill Military Academy had been served and a January 15, 1924 hearing

date was set. Joseph A. Hill, president of the school, declared that

we want to know right now where we stand. The very prospect of the operation of the law is costing us money, because of the fact that parents are looking for some school that the law will not reach. We cannot afford to wait until the law actually becomes operative to determine what damage will be done to us then; the very prospect of its going into effect is damaging us and will continue to damage us until the constitutionality of the law is determined by the supreme court of the United States. ${ }^{41}$

Circuit Judge W.B. Gilbert and District Judges C.E. Wolverton and R.S. Bean now heard arguments for both the Hill and Society of Sisters cases, which had been joined since they both pertained to the constitutionality of the school law. ${ }^{42}$ J.P. Kavanaugh presented the principle arguments for the Society; John S. Veatch represented the Hill Military Academy. The Sentinel once again reviewed the main points used by attorneys to demonstrate the unconstitutionality of the school law. The paper quoted Kavanaugh's argument to the effect that

this is not a regulatory statute. This is a statute of prohibition. It is the purpose of the state by this law to monopolize the entire field of education so far as it relates to those grades, creating a monopoly of education, removing it from the power of any other agency, however efficient, to exercise it at all. ${ }^{43}$

From January 24 through March 6, the Sentinel published installments of court transcripts with arguments by both sides. The transcript was then published as a pamphlet, written by A.B. Cain, and distributed by the Sentinel. The pamphlet

\footnotetext{
${ }^{41}$ Catholic Sentinel, December 20, 1923.

${ }^{42}$ Saalfeld, Forces of Prejudice, 91.

${ }^{43}$ Catholic Sentinel, January 17, 1924.
} 
published statements submitted to the voter's pamphlet, arguments presented before the court, and the court's decision. ${ }^{44}$ Another tactic involved publication of opinions from other parts of the country regarding the case. For example, the Sentinel quoted an editorial from the St. Louis Post Dispatch that expressed concern over the impending decision. "Religious prejudice, on the one hand, and social envy on the other," wrote the editors, "are plainly to be seen as the motives behind this Klan school law. If it is held constitutional, it will practically put every school in the State under Klan control." ${ }^{\text {45 }}$ The editorial was also critical of Oregon, claiming that should the law be upheld, the state would be ostracized by the rest of the Union for advocating a measure contrary to personal liberty. "It would spell ruin for Oregon and for any other state that should place itself in the same class of intolerance with regard to education, religion, and social life," the editors warned. ${ }^{46}$

On March 31, 1924, the three-man federal court found in favor of the plaintiffs and granted the injunction. The Sentinel devoted large sections of its April $3^{\text {rd }}$ edition to the verdict read to a crowded courtroom that included both supporters and opponents of the law. ${ }^{47}$ "The decision will have a far-reaching effect, and will tend to bring the people back to sane views of the constitutional rights of citizens," stated Kavanaugh, adding that a likely appeal to the U.S. Supreme Court would "settle the controversy for the whole country." 48 The court issued a preliminary injunction preventing the enforcement of the statute, stating that the lawsuit had not been filed

\footnotetext{
${ }^{44}$ Cain, The Oregon School Fight, 1.

${ }^{45}$ Catholic Sentinel, February 21, 1924.

46 Ibid.

${ }^{47}$ Catholic Sentinel, April 3, 1924.

${ }^{48}$ Ibid.
} 
pre-maturely, as claimed by the defense. In addition, the court claimed that the police powers of the state should not be "exercised arbitrarily and despotically." Lusk wrote that the lower court "held the bill deprived teachers and parents liberty and private schools their property per the Fourteenth Amendment, so the measure was void." $"$ According to the courts the purpose of the school bill was "to take utterly away from complainants their constitutional right and privilege to teach in the grammar grades and has and will deprive them of their property without due process of law." 51 It was the court's opinion that the defendants showed no compelling evidence that the new law was a necessity. As predicted, the court based its decision on the February 1923 decision in the Meyer v. Nebraska case. In that decision, the U.S. Supreme Court held that states could not prevent private schools from teaching foreign languages. The Court felt that the Meyer decision was applicable to the Oregon situation. ${ }^{52}$ If private schools were protected in their rights to teach foreign languages, then they also had the right to exist, making the Oregon school law unconstitutional.

In response to the defeat, officials from the state of Oregon appealed to the United States Supreme Court. The Sentinel was cautiously optimistic about a positive outcome and yet warned that, "the forces of intolerance will now shift their attack on private schools. Not being able to destroy these schools they will attempt to put them in a straitjacket of regulation governing textbooks and the minutiae of the

\footnotetext{
49 Tyack, "The Perils of Pluralism," 94.

${ }^{50}$ Lusk, The Fight For Educational Freedom, 10.

${ }^{51}$ Tyack, "The Perils of Pluralism," 95.

${ }^{52}$ Lusk, The Fight For Educational Freedom, 10.
} 
curriculum." ${ }^{, 53}$ The Sentinel had grounds for concern as the Klan vowed to continue its support for compulsory public school education, promoting a bill in Washington similar to the measure passed in Oregon. ${ }^{54}$ In fact, prior to the March 31 , 1924 decision on the Oregon school law, the Sentinel published several articles about the development of the compulsory measure in Washington. Of note was a lengthy article that discussed the formation of a conference called to counteract Klan propaganda against Washington's public schools. ${ }^{55}$ "The consensus of opinion is that, although schools established by Catholics, Presbyterians, Lutherans, Adventists and others would be directly affected by the proposed initiative measure, the attack fundamentally is one against inherent liberties of all citizens and must be met as such," reported the Sentinel. ${ }^{56}$

${ }^{53}$ Catholic Sentinel, April 3, 1924.

54 Tyack, "The Perils of Pluralism," 95.

${ }^{55}$ Catholic Sentinel, February 7, 1924.

${ }^{56}$ Ibid. 
Chapter 5

The United States Supreme Court Decision

While Oregonians awaited news of a U.S. Supreme Court hearing date, the Catholic Sentinel published a variety of articles related to the impending decision. For example, the paper ran a story touting the merits of private schools. In reporting about the annual convention of the National Education Association, the Sentinel reported that the association extended praise and support for the efforts of private schools, saying that the nation's children needed all schools, including both those of a religious and private nature. ${ }^{1}$ The paper stated that

the National Education association, while recognizing the American public school as the great nursery of broad and tolerant citizenship and education by private institutions and of a democratic brotherhood, acknowledges also the contributions made to enterprises, and recognizes that citizens have the right to educate their children in either public or private schools, when the educational standards of both are approved by the state educational authorities. ${ }^{2}$

One speaker at the convention, Dr. Payson Smith, a commissioner of education from Massachusetts, warned of the continued efforts of the Ku Klux Klan to exert influence on American education. "There are, unfortunately," Smith suggested, "some of our adult fellow-citizens, in a minority, we must believe-who seem to think that they can

${ }^{1}$ Catholic Sentinel, July 10, 1924.

${ }^{2}$ Ibid. 
serve their country by trying to array class against class, section against section and racial group against racial group. These citizens are wrong."

The Sentinel also reminded readers of the Catholic Truth Society's continued efforts to refute misinformation about the Church. Such efforts included the distribution of Catholic literature to non-Catholics, the printing of advertisements in local newspapers, and personal correspondence to inquiries regarding Catholic faith and practices. ${ }^{4}$ In particular, the paper expounded on the importance of counteracting Klan lectures. The Truth Society obtained mailing lists, and after any anti-Catholic or Klan lecture in any given town, mailed literature to households to "serve as an antidote for the poison which the "anti' injected."5 The Sentinel reminded readers about the dangers of allowing anti-Catholic sentiments to go unchecked. "Representative democracy is the best form of government so far established among men," the editors warned, "but even democratic government can be tyrannous at times; the safeguards provided by the fathers of the constitution against hasty popular opinion are not lightly to be set aside." "The light-hearted fashion in which a majority of Oregon voters two years ago trampled upon their neighbors' rights in the educational field shows that the Jeffersonian jealousy of power must be vigilantly maintained," they emphasized. ${ }^{7}$ Nevertheless, the Sentinel took comfort in the fact that "defenders of the private schools in the states of Washington and Michigan, where compulsory public school attendance bills were overwhelmingly defeated in the last election, declare their

\footnotetext{
${ }^{3}$ Ibid.

${ }^{4}$ Catholic Sentinel, September 18, 1924.

${ }^{5}$ Ibid.

${ }^{6}$ Catholic Sentinel, October 16, 1924.

${ }^{7}$ Ibid.
} 
success to have been largely due to the wide publicity given the unfair Oregon measure. ${ }^{8}$

As the Supreme Court hearing date neared in 1925, the Sentinel reiterated the main arguments. The hearing, suggested the editors, would focus mainly on the constitutionality of the law and technical issues involving the right of private schools to bring suit. ${ }^{9}$ The paper cited the attorney general's brief to demonstrate that the state sought to reduce the argument from the Society of Sisters to simply a religious issue since the language of the school bill did nothing outright to deny religious freedom. Attorney General Van Winkle wrote that if the state were denied the right to require that all children be educated in public schools, then "religious denominations may, without constitutional restrictions, develop a system of educational training which will result in doing away with public schools."10

In March, the Sentinel devoted a major section of the paper to the hearing. Interest in the case was high among the justices, it reported, noting that they frequently interrupted W. S. Moore, the assistant attorney general for the state of Oregon who opened the arguments for the state, with questions about the exact provisions of the law and its practicality. ${ }^{11}$ The paper then reported on the arguments presented by William D. Guthrie, an attorney from New York, who represented the Society of Sisters. Guthrie reminded the court of the Society's long history of service in Oregon. He emphasized that the qualifications and moral character of parochial school teachers

\footnotetext{
${ }^{8}$ Catholic Sentinel, December 18, 1924.

${ }^{9}$ Catholic Sentinel, February 12, 1925.

${ }^{10}$ Ibid.

"Catholic Sentinel, March 19, 1925.
} 
was not in question. The sole concern regarding institutions operated by the Society, Guthrie stressed, was the fact that they were Catholic schools, a premise he described as "inexcusable and cruel." Guthrie also argued that if the school law was found constitutional, any dominant political group in any given state could exercise unchecked control over education, preventing true freedom of opinion and religion. ${ }^{12}$

Guthrie pointed out that private and religious schools in America had existed from the nation's start. Even the Founding Fathers had received their educations from private and religious schools, some which were the best educational institutions in the country, he noted. ${ }^{13}$ The school bill, he warned, represented a viable threat to schools all the way to the collegiate level; this was particularly troubling given that there appeared to be no issue with the performance of private schools compared to their public counterparts. ${ }^{14}$ Guthrie also attacked the state claim that the school measure was necessary to prevent the teaching of radicalism. The state already possessed adequate power to combat these teachings if need be, he argued. For example, in Gilbert v. Minnesota (1920), the Court had ruled that states had the power to forbid the "teaching of disloyalty, sedition, and pacifism." In addition, said Guthrie, the state issued teacher licenses, giving it sufficient policing power over all educational institutions. "There is no doubt," he contended, "that this Court has repeatedly and

\footnotetext{
${ }^{12}$ Ibid.

${ }_{13}^{13}$ Pierce v. Society of the Sisters of the Holy Names of Jesus and Mary, 268 U.S. 510 (1925), 515.

${ }^{14}$ Ibid.

${ }^{15}$ Ibid, 516.
} 
authoritatively refused to countenance destruction of honest and ordinary

businesses charged with abuses which were readily remediable by regulation."16

Guthrie moved on to the assertion that public schools were the necessary vehicle for the assimilation of foreigners into American society. As the Court had ruled in Meyer v. Nebraska, he argued, public schools did not represent melting pots because they were located in within specific neighborhoods and reflected the character and population of that area. Therefore, assimilation was just as likely to occur in a private school as it could in a public facility. There was no justification to support claims that private schools were doing less of a job in teaching American values, said Guthrie:

The private and parochial schools teach the same subjects as the public schools-whatever one does to inculcate and foster patriotism, the other can and does quite well. No legislation can proscribe social discrimination, and the statute in the case at bar is singularly inappropriate to that end. How the act in suit could accomplish that result, no one can tell; and, as a reason for annihilating the appellee's useful and honorable business, it amounts to nothing. ${ }^{17}$

While conceding that compulsory education was necessary, Guthrie contended that the school law did so based on the false pretext that private and public schools could not co-exist, a false premise given the "long experience" of private and public schools operating simultaneously throughout American history. ${ }^{18}$ Furthermore, school decisions were for parents to make, not the state, as the denial of parental rights to

\footnotetext{
${ }^{16}$ Ibid.

${ }^{17}$ Ibid., 517.

18 Ibid., 518.
} 
send their children to private institutions constituted a violation of personal liberty and freedom. "It is not seriously debatable," he stated:

that the parental right to guide one's child intellectually and religiously is a most substantial part of liberty and freedom of the parent. But the power of the State to provide public schools carries with it no power to prohibit and suppress private schools and colleges which are competent and qualified to afford what the State wants, namely, education. ${ }^{19}$

The purpose of the Fourteenth Amendment, Guthrie emphasized, was to keep states from crafting laws that kept one group subjugated to the whim of another in terms of economic or social advancement. "The social interests menaced by the suppression of private educational institutions and the denial of liberty to pursue long rooted habits and traditions among our people are," Guthrie argued, "peculiarly of the character that the Fourteenth Amendment was most immediately designed to protect from state political action. ${ }^{20}$ Under the Fourteenth Amendment, he stated, the bill created "irreparable injury to business and property," and involved an unnecessary use of the power of the state over private property, ${ }^{21}$

Willis S. Moore, an attorney for Governor Walter Pierce, presented the arguments for the state. He argued that the Fourteenth Amendment did not restrict the power of the state to enact laws necessary to protect the general welfare of the people. ${ }^{22}$ In addition, corporation contracts were "subject to modification and annulment under the police power [of the state]. ${ }^{, 23}$ In particular, with minors

\footnotetext{
19 Ibid., 519.

${ }^{20}$ Ibid., 520.

${ }^{21}$ Ibid., $5 \mathrm{I} 3$.

22 Ibid., 511.

${ }^{23}$ Ibid., 512.
} 
involved, the state could potentially exercise unlimited control over such contracts without violating religious freedom. Because of the separation of church and state, "the public schools shall be maintained and conducted free from influences in favor of any religious organization, sect, creed, or belief." 24

George E. Chamberlain, arguing on behalf of Governor Walter Pierce, stated that the school law did not impair contracts nor did it deprive the Society of property without due process. Chamberlain also stated that there was no intention to close private schools, as they could still operate under the new school law. Students who fell either under or over the age parameters established by the new law could still attend private schools. Furthermore, public schools needed more teachers, so private school teachers could potentially seek employment there. ${ }^{25}$ Chamberlain argued that the liberty of school children would remain unaffected by the school measure because parents or the state made decisions regarding education. Therefore, if anyone were denied liberty by the new school measure, it would be parents. Chamberlain argued, however, that because public schools were in session for a limited number of hours, ample time existed within the context of a day for religious instruction, ensuring that parents were not deprived of any rights. ${ }^{26}$ He suggested that even in the freest societies, no one could enjoy unlimited liberty, as citizens have duties to the state deemed necessary by proper legislation. Chamberlain stated that, "the liberty of all is subject to reasonable conditions deemed essential by the governing body to the safety,

\footnotetext{
24 Ibid., 513.

${ }^{25}$ Ibid., 523.

${ }^{26}$ Ibid., 525.
} 
health, peace, good order and morals of the community."27 He also suggested that Oregonians voted for the school measure due to increased concerns about the stability of American society. "The discretionary powers of a State are broad enough," he stated, "to permit it to decide that compulsory attendance at public schools is a proper precautionary measure against the moral pestilence of paupers, vagabonds, and possible convicts. $" 28$

Chamberlain contended that the separation of children along religious lines, something that happened when some attended private schools while others attended public schools, prompted Oregonians to vote for the school measure. "The voters of Oregon might have felt," he suggested, "that the mingling together, during a portion of their education, of the children of all races and sects, might be the best safeguard against future internal dissentions and consequent weakening of the community against foreign dangers. ${ }^{\text {,29 }}$ Chamberlain insisted that concerns regarding the assimilation of immigrants warranted the passage of the school bill. While the federal government controlled the numbers of immigrants admitted into the country, the states did not have a say on the influx or residency of immigrants once they arrived. Therefore, it would be unfair not to allow the states the opportunity to take measures to "Americanize" newcomers so that they were, according to Chamberlain, "patriotic and law abiding." "S0 "Surely a State," he argued, "can require of all immigrants admitted to the advantages and opportunities of life in the United States, that their

\footnotetext{
${ }^{27}$ Ibid., 524.

28 Ibid.

${ }^{29}$ Ibid., 525.

${ }^{30}$ Ibid., 526.
} 
children shall be taught by the State the English language, and the character of American institutions and government." ${ }^{, 31}$ Finally, Chamberlain pointed out that the Supreme Court had held that the state had a responsibility for the care of minor children in child labor cases. The school measure simply removed exceptions from the former law so as to prevent the denial of equal protection in the future. If compulsory education laws were constitutional in other states, he concluded, the law in Oregon should stand as well because it fell under the broad definition of a state's police powers. ${ }^{32}$

Kavanaugh, the lead attorney for the Society during district court proceedings in Portland, presented closing rebuttal arguments. Chamberlain, a former U.S. Senator for Oregon, closed the state's arguments. The Sentinel simply commented that Chamberlain's arguments asserted that the purpose of Catholic schools was to separate Catholic children from other children, making them different from others as they grew up. This, it quoted Chamberlain, was a detriment to the overall development of democracy. Bringing all children together in public schools served as the great equalizer in a truly democratic nation, the paper quoted the attorney as saying. ${ }^{33}$ In contrast to this brief summary of the state's cases the Sentinel elected to use two editions to print an extensive summary of Kavanaugh's closing arguments. It reported that Kavanaugh reminded the Court that the Fourteenth Amendment protected the operation of a private school and that the school law represented an attempt to deny the Society the right to operate such schools. Kavanaugh argued that the true intent of

\footnotetext{
31 Ibid, 525.

32 Ibid., 527.

${ }^{33}$ Catholic Sentinel, March 19, 1925.
} 
the Oregon school law was to close private Catholic institutions. In doing so, the school law violated the property rights of the Society as protected by the contract and business charter the Society held with the state. In addition, the law violated the right of parental control over the education of their children. Kavanaugh also stated that the school law represented an overextension of the state's police power. According to Kavanaugh, because the school law contained no regulatory provisions, it represented an arbitrary use of police power by the state. ${ }^{34}$ Finally, Kavanaugh explained to the Court that even before the law was to go into effect in 1926, private schools were already seeing a decline in enrollment, another result of the inappropriate use of the state's police powers. ${ }^{35}$

On June 1, 1925, the U.S. Supreme Court ruled in a unanimous vote to uphold the decision of the district court and struck down the Oregon compulsory public education law. The Court, as stated in the opinion written by Associate Justice James C. McReynolds, agreed with the lower tribunal that Oregon private schools had been deprived of their property without due process of law as guaranteed by the Fourteenth Amendment. As Justice McReynolds stated, "Without doubt enforcement of the statute would seriously impair, perhaps destroy, the profitable features of the appellee's business and greatly diminish the value of their property. ${ }^{36}$ In essence, the Court disagreed with the state's argument that private schools were unnecessary and divisive. $^{37}$

\footnotetext{
${ }^{34}$ Ibid.

${ }^{35}$ Catholic Sentinel, March 26, 1925.

${ }^{36}$ Pierce v. Society of the Sisters of the Holy Names of Jesus and Mary, 268 U.S. 510 (1925), 531.

${ }^{37}$ Hennesey, American Catholics, 247.
} 
While the Court's decision was grounded on the issue of property rights, it also made general comments about education that have helped shape modern views regarding compulsory education. ${ }^{38}$ In particular, the Court felt there was no question that the state could reasonably regulate all schools. At the same time, private schools "were engaged in an undertaking not inherently harmful, but long regarded as useful and meritorious." ${ }^{.39}$ Therefore, the new law unreasonably interfered with the right of parents to regulate the education of their children. ${ }^{40}$ The Court's unanimous opinion clearly communicated that states had the right to regulate all schools, but they could not make public school attendance compulsory. ${ }^{41}$ As McReynolds wrote, "The child is not the mere creature of the State; those who nurture him and direct his destiny have the right, coupled with the high duty, to recognize and prepare him for additional obligations."42 Finally, McReynolds wrote that the Society was "threatened with destruction through the unwarranted compulsion which appellants are exercising over present and prospective patrons of their schools. And this Court has gone very far to protect against loss threatened by such action." ${ }^{43}$ McReynolds, therefore, acknowledged that the requested injunctions preventing the law from going into effect were legitimate. "The injury to appellees was present and very real, not a mere possibility in the remote future," he stated. "If no relief had been possible prior to the effective date of the Act, the injury would have become irreparable. Prevention of

\footnotetext{
38 Tyack, "The Perils of Pluralism," 97.

${ }^{39}$ Pierce v. Society of the Sisters of the Holy Names of Jesus and Mary, 268 U.S. 510 (1925), 534.

${ }^{40}$ Tyack, "The Perils of Pluralism," 97.

${ }^{41}$ Hennesey, American Catholics, 248.

${ }^{42}$ Pierce v. Society of the Sisters of the Holy Names of Jesus and Mary, 268 U.S. 510 (1925), 535.

${ }^{43}$ Ibid.
} 
impending injury by unlawful action is a well recognized function of courts of equity."

The school law case generated widespread interest and has been hailed by Catholic historian James Hennesey as "the Magna Carta for Catholic education in the United States." ${ }^{\text {A5 }}$ Although Archbishop Christie passed away just before the final court decision, his efforts generated a more positive outlook for the future of Catholic schools in Oregon. ${ }^{46}$ When the Sentinel announced the decision in its June 4, 1925 edition, it reminded readers that the Court had reached a unanimous decision to overturn an initiative passed during the contentious 1922 election where religion had figured prominently in the campaign. ${ }^{47}$ Recapping the campaign against the school bill, the paper complimented the Catholic Civic Rights Association and expressed gratitude for the efforts of other religious groups, specifically the Lutherans and Seventh Day Adventists. The Sentinel also noted how the National Catholic Welfare Conference, representing the bishops of the United States, assumed financial responsibility for the lawsuit.

The Sentinel's full coverage of the Supreme Court decision included an article in which attorney John P. Kavanaugh commented on the significance of the case. Kavanaugh believed that the Court's opinion was decisive enough to prevent the passage of similar bills in the future. "No appeals to passion or prejudice are of any avail," he wrote. "The courts will not approve undue restraints upon liberty or

\footnotetext{
${ }^{44}$ Ibid., 536.

${ }^{45}$ Hennesey, American Catholics, 248.

${ }^{46}$ Saalfeld, Forces of Prejudice, 92.

${ }^{47}$ Catholic Sentinel, June 4, 1925.
} 
destruction of property, unless the advocate can show some present danger or existing emergency. We shall not hear of this measure again in our generation. ${ }^{, 48}$ The Sentinel editorialized that it was appalling that so many Oregonians had forgotten the basic foundations that the American government was founded on. Yet, the decision reminded Americans that the government "excludes any general power of the state to standardize its children by forcing them to accept instruction from public teachers only. The child is not the mere creature of the state.,"49 
Conclusion

Post Pierce Prejudice

Although the $\mathrm{Ku}$ Klux Klan struggled to maintain its momentum throughout 1923 and into 1924, anti-Catholic advocates in Oregon remained committed to undermining the perceived influence and political power of the Catholic Church. As historian Lawrence Saalfeld commented, "the Multnomah County elections occasioned some of the most bitter anti-Catholic bigotry in the history of the Klan. All those who were opposed to the Klan slate of candidates were immediately linked with the imaginary 'great Catholic machine', despite the fact that some of the opponents were known to have sympathized with the Klan." The defeat of Klan candidates in this election, Saalfeld added, signified the end of the secret order's domination of Portland politics. ${ }^{2}$ Historian David Chalmers has echoed these sentiments by arguing that while the Klan held political power in Oregon, it did not mean that it exercised complete control. For example, Chalmers pointed out that while the Klan introduced a number of bills into the Oregon state legislature aimed at reducing supposed Catholic power within the state, many of the proposed laws failed. In addition, Governor Walter Pierce refused to grant sweeping patronage jobs to Klansmen in return for electoral support during the 1922 campaign. ${ }^{3}$ Furthermore, the

\footnotetext{
${ }^{1}$ Saalfeld, Forces of Prejudice, 42.

${ }^{2}$ Ibid., 43.

${ }^{3}$ Chalmers, Hooded Americanism, 89.
} 
1924 Senate race contributed to the demise of the Oregon Klan because Klan members were divided on which candidate to support. ${ }^{4}$

By the mid-1920s, Klan influence appeared to be waning throughout the West as the Invisible Empire proved incapable of resolving issues in local communities. ${ }^{5}$ Though the Klan attempted to be the voice of the common people, more often than not, Klansmen eventually found themselves at odds with community leaders. ${ }^{6}$ Klan members in Oregon and elsewhere also failed to establish a long-term political base. These political setbacks, along with infighting among Klan leaders, contributed to the organization's decline. Most importantly, the Klan was a victim of its own secrecy, leading to accusations of conspiracy and corruption. ${ }^{7}$

At the same time, however, the Catholic Sentinel reminded its readers of the origins of the school bill and that the reasoning behind the bill's passage had not faded as a result of the Supreme Court's decision. The Sentinel stated "there must always remain a great regret that it was necessary to appeal to the courts for protections from the misguided action of fellow citizens of the commonwealth." ${ }^{8}$ The paper cautioned against complacency by reminding readers that the "ghost of religious prejudice has not been laid and it is incumbent on Catholics to carry on an energetic campaign of education among their non-Catholic neighbors." "Could we have prevented the

\footnotetext{
${ }^{4}$ Ibid., 90 .

${ }^{5}$ Shawn Lay, "Robe and Gown: The Ku Klux Klan in Eugene, Oregon during the 1920s," in The Invisible Empire of the West: Toward a New Historical Appraisal of the Ku Klux Klan of the 1920s, ed. Shawn Lay (Chicago: University of Illinois Press, 2004), 217.

${ }^{6}$ Ibid., 219.

${ }^{7}$ Ibid., 221.

${ }^{8}$ Catholic Sentinel, June 4, 1925.

${ }^{9}$ Ibid.
} 
passage of the school measure," the editors asked, "if we had been diligent in informing our separated brethren of our educational aims?"10

At first glance, today's Catholics appear to have escaped the viciousness of anti-Catholic rhetoric. Author Mark Massa explained that the election of John F. Kennedy, the reforms of the Second Vatican Council, and the middle-class affluence of Catholic groups such as the Irish, the Italians, and the Poles all point to the disappearance of anti-Catholicism. " However, Massa also cited a 1977 study published by sociologist Andrew Greeley that suggested that a new anti-Catholicism simmered during the last quarter of the twentieth century. Greeley wrote that the foundation behind modern anti-Catholic views was not really new at all but based on long-held prejudices about the Church. ${ }^{12}$ Catholicism is the church in the United States and based on a highly organized hierarchy of leadership. It holds what many consider to be controversial views on sexuality, gender, and education. According to Massa and Greeley, these views fuel old concerns that the teachings of the Catholic Church contradict the values of a modern, democratic society. ${ }^{13}$ Massa wrote that Catholics in the United States have always, and still are, viewed as "outsiders" and "others" in a society still influenced and shaped by Protestant concepts and values. ${ }^{14}$ Historian Robert Lockwood echoed Massa's views in a study of antiCatholicism in American society. Both Lockwood and Massa pointed to the negative portrayals of the Catholic Church in the media as strong evidence that anti-Catholic

\footnotetext{
${ }^{10}$ Ibid.

"Massa, Anti-Catholicism in America, 40.

${ }^{12}$ Ibid., 41.

${ }^{13}$ Ibid.

14 Ibid., 198.
} 
sentiment persists in the United States. Lockwood wrote that employing antiCatholic rhetoric remains a popular strategy in a culture that is "all-embracing, secular, and rational. ${ }^{15}$ "The assumed prejudice is that Catholicism-an "alien religion"-cannot and should not be allowed to have any real part in the continuing conversation of public debate as it represents an un-American view," he suggested. ${ }^{16}$ Lockwood even cited the controversy surrounding Oregon's Death with Dignity Act, passed in 1994 by voters who also rejected an attempt to repeal the act in 1997. Lockwood argued that the measure passed not because of any real debate on the suicide issue itself but because proponents characterized the Church as an out-dated, foreign entity that had no place in the political affairs of Oregonians. ${ }^{17}$

In his history of the Catholic Sentinel, Wilfred Schoenberg also commented on the prevalence of anti-Catholic views in modern society. For example, Schoenberg wrote of several editorials published in the Sentinel regarding the Broadway play Sister Mary Ignatius Explains It All for You, performed at several college and university campuses around Oregon in the early 1980s. In response, the Sentinel editor, Fritz Meagher wrote that the play recalled some of the familiar bigotry against the Church. ${ }^{18}$ "What purports to be a witty, humorous satire of Catholic parochial education and Catholic teachings," wrote Meagher, "is really nothing more than a hateful, ill-humored and grotesque put-down of things Catholic. What passes for

\footnotetext{
${ }^{15}$ Lockwood, Anti-Catholicism in American Culture, 47.

${ }^{16}$ Ibid.

${ }^{17}$ Ibid., 45.

${ }^{18}$ Schoenberg, Defender of the Faith, 376.
} 
humor would bore an audience of Klansmen."19 Schoenberg believed, therefore, that the Sentinel was still fulfilling its original role as the defender of the Catholic faith in Oregon. ${ }^{20}$ The fact that the Catholic Truth Society survived into the $1980 \mathrm{~s}$ is significant evidence that Church leaders believe that anti-Catholic views continue to thrive. It is important to recognize that the Catholic Truth Society was not dismantled because it was deemed unnecessary. Today, the work of the Catholic Truth Society is encompassed into a larger organization, the Oregon Catholic Press. ${ }^{21}$ While this certainly suggests the need to remain vigilant in defending the Church against bigotry, more importantly, it speaks to the importance of disseminating accurate information. In the end, the strongest line of defense against any prejudice is education.

\footnotetext{
${ }^{19}$ Catholic Sentinel, January 21, 1983.

${ }^{20}$ Schoenberg, Defender of the Faith, 376.

${ }^{21}$ Ibid., 363.
} 
Sources Consulted

\section{Primary Sources}

Cain, A.B. The Oregon School Fight: A True and Complete History. Portland, Oregon: A.B. Cain, Publisher, 1924.

Estes, George. The Old Cedar School. Troutdale, Oregon: Luther I. Powell, Publisher, 1922.

Lusk, Hall S. The Fight For Educational Freedom.

Meyer v. Nebraska. 262 U.S. 390 (1923).

Pierce v. Society of the Sisters of the Holy Names of Jesus and Mary. 268 U.S. 510 (1925).

State v. Scopes. 152 Tenn. 424, 278 S.W. 57 (Tenn. 1926).

Strong, Josiah. Our Country. Edited by Jurgen Herbst. Cambridge, Massachusetts: Harvard University Press, 1963.

Washington, George. The Papers of George Washington: 1732-1799, Volume Two. Edited by Philander D. Chase. Charlottesville, Virginia: University Press of Virginia, 1987.

Wooten, Dudley. Twenty-Four Reasons. Portland, Oregon: Catholic Civil Rights Association, 1922.

\section{Newspapers}

The Catholic Sentinel, April 1, 1871.

The Catholic Sentinel, June 24, 1880.

The Catholic Sentinel, December 5, 1901. 
The Catholic Sentinel, June 10, 1915.

The Catholic Sentinel, June 15, 1916.

The Catholic Sentinel, March 2, 1922.

The Catholic Sentinel, March 23, 1922.

The Catholic Sentinel, March 30, 1922.

The Catholic Sentinel, April 6, 1922.

The Catholic Sentinel, April 13, 1922.

The Catholic Sentinel, April 27, 1922.

The Catholic Sentinel, May 4, 1922.

The Catholic Sentinel, May 18, 1922.

The Catholic Sentinel, May 25, 1922.

The Catholic Sentinel, June 1, 1922.

The Catholic Sentinel, June 15, 1922.

The Catholic Sentinel, July 13, 1922.

The Catholic Sentinel, July 20, 1922.

The Catholic Sentinel, July 27, 1922.

The Catholic Sentinel, August 24, 1922.

The Catholic Sentinel, September 28, 1922.

The Catholic Sentinel, October 5, 1922.

The Catholic Sentinel, October 26, 1922.

The Catholic Sentinel, November 9, 1922.

The Catholic Sentinel, November 16, 1922. 
The Catholic Sentinel, November 23, 1922.

The Catholic Sentinel, November 30, 1922.

The Catholic Sentinel, December 7, 1922.

The Catholic Sentinel, December 28, 1922.

The Catholic Sentinel, January 11, 1923.

The Catholic Sentinel, January 18, 1923.

The Catholic Sentinel, January 25, 1923.

The Catholic Sentinel, February 1, 1923.

The Catholic Sentinel, February 8, 1923.

The Catholic Sentinel, February 15, 1923.

The Catholic Sentinel, February 22, 1923.

The Catholic Sentinel, March 1, 1923.

The Catholic Sentinel, March 8, 1923.

The Catholic Sentinel, March 15, 1923.

The Catholic Sentinel, June 7, 1923.

The Catholic Sentinel, July 12, 1923.

The Catholic Sentinel, August 23, 1923.

The Catholic Sentinel, September 14, 1923.

The Catholic Sentinel, October 25, 1923.

The Catholic Sentinel, November 29, 1923.

The Catholic Sentinel, December 20, 1923.

The Catholic Sentinel, January 17, 1924. 
The Catholic Sentinel, February 7, 1924.

The Catholic Sentinel, February 21, 1924.

The Catholic Sentinel, April 3, 1924.

The Catholic Sentinel, May 15, 1924.

The Catholic Sentinel, July 10, 1924.

The Catholic Sentinel, September 18, 1924.

The Catholic Sentinel, October 16, 1924.

The Catholic Sentinel, December 18, 1924.

The Catholic Sentinel, February 12, 1925.

The Catholic Sentinel, March 19, 1925.

The Catholic Sentinel, March 26, 1925.

The Catholic Sentinel, June 4, 1925.

The Catholic Sentinel, June 11, 1925.

The Oregonian, November 5, 1921.

The Oregonian, May 15, 1922.

The Oregonian, September 13, 1922.

The Oregonian, September 17, 1922.

The Oregonian, November 2, 1922.

The Oregonian, November 9, 1922.

The Oregonian, November 23, 2009.

The Oregon Voter, March 25, 1922.

The Oregon Voter, November 23, 1922. 
The Portland Telegram, January 25, 1894.

The Portland Telegram, October 24, 1922.

The Portland Telegram, October 25, 1922.

The Portland Telegram, October 26, 1922.

\section{$\underline{\text { Secondary Sources }}$}

Bunch, Ralph E. "Pierce v. Society of Sisters: The Oregon School Case." (Master's thesis, University of Oregon, 1961).

Chalmers, David. Hooded Americanism: The History of the Ku Klux Klan. Durham: Duke University Press, 1987.

Clark, Jr., Malcolm. "The Bigot Disclosed: Ninety Years of Nativism." In Oregon Historical Quarterly. 75, no. 2 (June 1974).

Dodds, Gordon B. Oregon: A History. New York: W.W. Norton and Company, Inc., 1977.

Dolan, Jay P. The American Catholic Experience: A History from Colonial Times to the Present. Notre Dame, Indiana: University of Notre Dame Press, 1992.

Hennesey, S.J., James. American Catholics: A History of the Roman Catholic Community in the United States. New York: Oxford University Press, 1981.

Holsinger, M. Paul. "The Oregon School Controversy, 1922-1925." In Pacific Historical Quarterly. 37 (August 1968).

Horowitz, David A., ed. Inside The Klavern: The Secret History of a Ku Klux Klan of The 1920s. Carbondale, Illinois: Southern Illinois University Press, 1999. , America's Political Class Under Fire: The Twentieth Century's Great Culture War. New York: Routledge, 2003.

, "The Klansman as Outsider: Ethnocultural Solidarity and Antielitism in the Oregon Ku Klux Klan of the 1920s." In Pacific Northwest Quarterly. 80, no. 1 (January 1989). 
, "Order, Solidarity, and Vigilance: The Ku Klux Klan in La

Grande, Oregon." In The Invisible Empire in the West. Toward a New

Historical Appraisal of the Ku Klux Klan of the 1920s, edited by Shawn Lay,

185-204. Chicago: University of Illinois Press, 2004.

Huffman, Robin. "An Analysis of the Interrelationship Between the Oregon School

Law of 1922, the Press of Oregon, the Election of Walter Pierce and the

K.K.K." (Master's thesis, Portland State University, 1974).

Jackson, Kenneth T. The Ku Klux Klan in the City: 1915-1930. New York:

Oxford University Press, 1967.

Jacobson, Matthew Frye. Whiteness of a Different Color: European Immigrants and the Alchemy of Race. Cambridge, Massachusetts: Harvard University Press, 1998.

Johnston, Robert D. "Middle Class Political Ideology in a Corporate Society: The Persistence of Small-Propertied Radicalism in Portland, Oregon, 1883-1926." PhD diss., Rutgers University, 1993.

Kelly, Alfred H., Winfred A. Harbison, and Herman Belz. The American Constitution: Its Origins and Development, Volumes I and II. New York: W.W. Norton and Company, 1991.

Kinzer, Donald. An Episode in Anti-Catholicism: The American Protective Association. Seattle: University of Washington Press, 1964.

Lockwood, Robert P., ed. Anti-Catholicism in American Culture. Huntington, Indiana: Our Sunday Visitor, Inc., 2000.

Massa, S.J., Mark S. Anti-Catholicism In America: The Last Acceptable Prejudice. New York: Crossroad Publishing Company, 2003.

McCoy, Robert R. "The Paradox of Oregon's Progressive Politics: The Political Career of Walter Marcus Pierce." In Oregon Historical Quarterly. 110, no. 2 (Fall 2009).

Saalfeld, Lawrence J. Forces of Prejudice in Oregon: 1920-1925. Portland, Oregon: University of Portland Press, 1984.

Schoenberg S.J., Wilfred. Defender of the Faith. Portland, Oregon: Oregon Catholic Press, 1993. 
Toy, Eckard V. "Robe and Gown: The Ku Klux Klan in Eugene, Oregon during The 1920s." In The Invisible Empire in the West. Toward a New Historical Appraisal of the Ku Klux Klan of the 1920s, edited by Shawn Lay, 153-179. Chicago: University of Illinois Press, 2004.

Tyack, David B. "The Perils of Pluralism: The Background of the Pierce Case." The American Historical Review, vol. 74, No. 1. (October, 1968), p.p. 74-98.

Urofsky, Melvin I. A March of Liberty: A Constitutional History of the United States. New York: McGraw-Hill Publishing Company, 1988. 